\title{
Role of Endoplasmic Reticulum Stress in the Anticancer Activity of Natural Compounds
}

\author{
Patrizia Limonta $₫$, Roberta M. Moretti, Monica Marzagalli $₫$, Fabrizio Fontana, \\ Michela Raimondi $[$ and Marina Montagnani Marelli * (1) \\ Department of Pharmacological and Biomolecular Sciences, Università degli Studi di Milano, \\ 20133 Milano, Italy; patrizia.limonta@unimi.it (P.L.); roberta.moretti@unimi.it (R.M.M.); \\ monica.marzagalli@gmail.com (M.M.); fabrizio.fontana@unimi.it (F.F.); michela.raimondi@unimi.it (M.R.) \\ * Correspondence: marina.marellimontagnani@unimi.it; Tel.: +39-02-5031-8225; Fax: +39-02-5031-8202
}

Received: 16 January 2019; Accepted: 18 February 2019; Published: 22 February 2019

\begin{abstract}
Cancer represents a serious global health problem, and its incidence and mortality are rapidly growing worldwide. One of the main causes of the failure of an anticancer treatment is the development of drug resistance by cancer cells. Therefore, it is necessary to develop new drugs characterized by better pharmacological and toxicological profiles. Natural compounds can represent an optimal collection of bioactive molecules. Many natural compounds have been proven to possess anticancer effects in different types of tumors, but often the molecular mechanisms associated with their cytotoxicity are not completely understood. The endoplasmic reticulum (ER) is an organelle involved in multiple cellular processes. Alteration of ER homeostasis and its appropriate functioning originates a cascade of signaling events known as ER stress response or unfolded protein response (UPR). The UPR pathways involve three different sensors (protein kinase RNA(PKR)-like ER kinase (PERK), inositol requiring enzyme1 $\alpha$ (IRE1) and activating transcription factor 6 (ATF6)) residing on the ER membranes. Although the main purpose of UPR is to restore this organelle's homeostasis, a persistent UPR can trigger cell death pathways such as apoptosis. There is a growing body of evidence showing that ER stress may play a role in the cytotoxicity of many natural compounds. In this review we present an overview of different plant-derived natural compounds, such as curcumin, resveratrol, green tea polyphenols, tocotrienols, and garcinia derivates, that exert their anticancer activity via ER stress modulation in different human cancers.
\end{abstract}

Keywords: ER stress; natural compounds; cancer; apoptosis; unfolded protein response

\section{Introduction}

Endoplasmic reticulum (ER)is the organelle in eukaryotic cells, described for the first time by Porter et al. in 1945 [1] after analyzing chicken fibroblasts by using electron microscopy. It appears as a membrane network including elongated tubules and flattened discs that span a great area of the cytoplasm. ER consists of the smooth and the rough ER that can exist either as interconnected or spatially separated compartments [2]. It is physically in contact with mitochondria in specific regions called mitochondria-associated membranes (MAMs) that play a very important role in $\mathrm{Ca}^{2+}$ homeostasis [3].

The ER performs many essential functions including folding and post-translational processing of membrane-bound and secreted proteins, lipid synthesis, degradation of glycogen, detoxification, and $\mathrm{Ca}^{2+}$ storage and release [4]. The proper ER luminal calcium concentration is also essential for its protein folding and posttranslational modification actions since molecules such as chaperonins, protein disulfide isomerases (PDIs), N-glycosylating proteins, and other enzymes need the correct oxidoreductase potential to work appropriately [5]. 
Various stress factors, such as hypoxia, starvation, oxidative insults, changes in $\mathrm{pH}, \mathrm{Ca}^{2+}$ depletion, hypoglycemia, ATP depletion, and viral infections, can disturb ER homeostasis. All these aspects can interfere with correct protein folding, finally leading to the accumulation of misfolded or unfolded proteins, generating a condition known as ER stress [6]. In response to such a stress state, cells have evolved an evolutionary conserved signal transduction pathway called UPR (unfolded protein response) whose principal aim is to restore ER homeostasis [7]. Three different ER transmembrane sensors, inositol requiring enzyme1 $\alpha$ (IRE1 $\alpha$ ), protein kinase RNA(PKR)-like ER kinase (PERK), and activating transcription factor 6 (ATF6) detect the unfolded or misfolded proteins accumulated in the ER and initiate three distinct UPR branches, respectively, to overcome stress and restore homeostasis. However, when the stress conditions are too intense and cannot be turned back, the UPR activates a cell death pathway, generally via intrinsic apoptosis involving the mitochondria [6]. For this reason, under toxic and unresolved stress conditions, UPR transforms the cell destiny from survival to death [8]. However, novel ER stress-independent functions of UPR are here described; in macrophages X-box binding protein1 (XBP1) mediates the secretion of pro-inflammatory cytokines by the Toll-like receptor, independently of ER stress activation [9]. XBP1 is important for secretory cells and for the formation of plasma cells. In B cells that differentiate to plasma cells, XBP1 activation is differentiation-dependent and not a UPR-dependent event [10].

Cancer represents one of the leading causes of death worldwide. The analysis presented in the GLOBOCAN report estimated 18.1 million new cases of cancers and 9.6 million cancer deaths in the world in 2018 [11].

Over the past several decades, the discovery of plant-based drugs contributed to develop anticancer drugs, some of which have been historically approved in United States by the Food and Drug Administration (FDA) such as paclitaxel, camptothecin, vincristine, and their analogs [12]. Natural compounds represent a heterogeneous ensemble of structures that can be exploited to develop future effective drugs. Natural compounds could be originated from plants, animals, and produced from microbes, and many of them have shown a low risk of side effects in clinical trials [13]. Natural compounds can be utilized in different manners in cancer management: as chemopreventive [14], as chemotherapeutic [15], or chemosensitizer agents [16]. For this reason, the research for new bioactive molecules present in natural compounds with antitumor capacity is highly encouraged.

In this review, we will examine some classes of natural compounds showing the ability to induce ER stress-related death in cancer cells. In particular, we will focus on preclinical studies (in vitro and in vivo approaches) by reporting the ER stress-related anticancer activity exerted by natural compounds, such as curcumin, resveratrol, green tea polyphenols, quercetin, garcinia, tocotrienols, and new recent other compounds, in different types of human cancers.

\section{Endoplasmic Reticulum Stress Response Pathways}

\subsection{UPR}

The UPR represents a cellular stress response starting in the ER, controlled by three distinct sensors, IRE1 $\alpha$, PERK, and ATF6. Normally the ER resident chaperone, known as glucose-regulated protein 78 (GRP78) or binding immunoglobulin protein (BiP) is bound to the ER luminal domain of the three sensors, maintaining them in an inactive state [17]. Once detached from BiP, IRE1 and PERK form homodimers or oligomers, and through autophosphorylation, activate their downstream pathways [17].

Upon release by BiP, the active form of ATF6 moves to the nucleus and promotes the transcription of different ER chaperones [8].

\subsection{IRE1 Pathway}

The IRE1 pathway is the most evolutionarily conserved arm of the UPR, activated in different processes, both physiological and pathological such as those inducing ERAD (ER-associated 
degradation) [18], lipid synthesis [19], and protein secretion [20]. IRE1 is a type I protein receptor with an N-terminal ER luminal sensing domain and a cytosolic C-terminus domain enclosing both an endoribonuclease domain and a Ser/Thr kinase domain. In humans, there are two IRE isoforms, IRE1 $\alpha$ and IRE1 $\beta$; the first one is expressed ubiquitously on the ER membranes, while the second one is found only on the epithelial cells of the gastrointestinal tract [8]. Upon ER stress condition, IRE1 $\alpha$ dissociates from $\mathrm{BiP}$, dimerizes, and autophosphorylates, converting to its active form. Once active, IRE1 $\alpha$ triggers its endonuclease activity responsible for X-box binding protein1 (XBP1) mRNA splicing. XBP1s (XBP1 spliced) mRNA encodes for a stable transcription factor targeting a range of genes involved in pro-survival responses [21]. However, IRE1 $\alpha$, in its active state, can activate another downstream signal through post-transcriptional modification of different substrates via regulated IRE1-dependent decay (RIDD) whose activation tends to trigger apoptosis. Hence, IRE1 $\alpha$ via oligomerization induces XBP1 mRNA splicing, whereas dimerization induces RIDD. Active IRE1 $\alpha$ also interacts with tumor necrosis factor receptor-associated factor 2 (TRAF2) leading to the increment of apoptosis signal-regulating kinase 1 (ASK1) and JUN N-terminal kinase (JNK), and in turn, induces apoptosis [22].

\subsection{PERK Pathway}

PERK is an ER transmembrane protein associated with BiP in its inactive form, but upon dissociation from $\mathrm{BiP}$ in response to UPR triggering, it is activated by oligomerization and autophosphorylation [8]. Active PERK attenuates mRNA translation and prevents the arrival of new proteins into the ER compartment. This action is mediated by phosphorylation-mediated inactivation of the eukaryotic translation initiation factor 2 (eIF2 $\alpha$ ). The phosphorylation of eIF $2 \alpha$ blocks the recycling of eIF $2 \alpha$ in its active GTP-bound state, needed for starting polypeptide chain synthesis, leading to the attenuation of general protein translation. This process is crucial for decreasing the ER protein burden and to resolve ER stress [23]. This block in protein translation is not absolute; indeed, in the meantime, eIF $2 \alpha$ phosphorylation paradoxically regulates the expression of activating transcription factor 4 (ATF4), a member of the CCAAT/enhancer binding protein family (C/EBP) family of transcription factors [24]. ATF4, in turn, regulates the expression of genes involved in the restoration of normal cellular homeostasis. Among its target genes, there is the pro-apoptotic C/EBP homologous protein (CHOP) [25]. CHOP and ATF4 upregulate the transcription of growth arrest and DNA-damage-inducible protein 34 (GADD34), which in turn causes the dephosphorylation of eIF2 $\alpha$. If ER stress is irreversible, ATF4-CHOP activation can induce the apoptotic pathway [26].

\subsection{ATF6 Pathway}

ATF6 is an ER transmembrane protein and a member of the leucine zipper family of transcription factors [27]. Two ATF6 homologues are expressed in mammalian cells: ATF6 $\alpha$ and ATF6 $\beta$. Following UPR activation, ATF $6 \alpha$ moves to the Golgi apparatus where it is processed by site- 1 and site- 2 proteases (S1P and $\mathrm{S} 2 \mathrm{P}$ ) and is transformed in a cytosolic fragment: cleaved ATF6 $\alpha$. In this active form, it translocates to the nucleus and acts as a transcription factor regulating the expression of genes presenting ATF/cAMP response elements or ER stress response elements (ERSE) within their promoter, such as BiP, and protein disulfide isomerase (PDI). Unlike ATF6 $\alpha$, ATF6 $\beta$ is not crucial in responses to UPR or regulation of ER chaperones. ATF6 $\beta$ has been shown to inhibit ATF6 $\alpha$-mediated activity during UPR [28]. A study also shows that ATF6 $\alpha$ regulates the transcription of ERAD components. Levels of ERAD components, including ER degradation-enhancing $\alpha$-mannosidase-like protein (EDEM), hydroxymethyl glutaryl-coenzyme A reductase degradation protein 1 (HRD1), and Herp, were found to be lower in ER stress-induced ATF $6 \alpha^{-/-}$mouse embryonic fibroblasts (MEFs) compared to ATF $6 \alpha^{+/+}$MEFs. While ATF6 activity is mainly pro-survival, during severe and sustained ER stress, it can increase CHOP expression that is associated with cell death [29]. 


\section{ER Stress Mediates UPR for Anticancer Strategies}

ER stress is primarily a pro-survival adaptive response against different types of cellular insults.

However, in the presence of severe, prolonged, and sustained ER stress conditions, ER stress-mediated UPR might fail to re-establish ER homeostasis and switches from pro-survival to pro-death mechanisms [6]. Although the molecular mechanisms related to this switching are not completely understood, it has been described that UPR utilizes some of the sensors and executioners of pro-survival components to activate a pro-death pathway in response to severe ER stress [8]. Cancer cells adapt UPR to alleviate the ER stress condition as a survival approach for progression [30]. UPR in cancer has also been described to participate in mechanisms involved in resistance to chemotherapy or radiation [31]. Some studies demonstrated that prolonged and severe ER stress can induce apoptosis, offering an interesting therapeutic rationale for suppression of cancer through the accumulation of unfolded proteins [8].

\subsection{Pro-Apoptotic Signals Involving IRE1 $\alpha-X B P 1$}

The IRE1 sensor is usually associated with pro-survival effects during ER stress conditions through the induction of different chaperones [32]. During severe and sustained ER stress, it has been shown that IRE1 $\alpha$ can activate a pro-apoptotic signaling. Activation of JNK represents one of the better-known mechanisms observed in the pro-death activity of IRE1 $\alpha$. This ER stress sensor activates JNK and IRE1 $\alpha$ knockout to reduce JNK activity, suggesting that IRE1 $\alpha$ represents an upstream activator of the JNK pathway. TRAF2 can mediate the JNK activation by IRE1 $\alpha$ [33]. In turn, JNK induces apoptosis by increasing reactive oxigene species (ROS) production, by enhancing the expression of pro-apoptotic BH3 only members and, in the opposite way, by reducing the expression of anti-apoptotic Bcl-2 family members. The pro-apoptotic proteins Bcl-2-associated X protein (Bax) and Bcl-2 homologous antagonist/killer (Bak) form complexes with cytosolic region of IRE1 $\alpha$ in response to ER stress inducers and are essential for IRE1 $\alpha$ signaling [34]. IRE1 $\alpha$, as previously discussed, could regulate XBP1 mRNA splicing to produce mature XBP1. Different studies indicated that the IRE1 $\alpha$-XBP1 signaling was observed in different human cancers including breast and hepatocellular cancer [35]. In breast cancer cells, XBP1's active form increases the tolerance of cells to hypoxia [20].

Under sustained ER stress, IRE1 $\alpha$ stimulates activation of RIDD to promote apoptosis. The molecular mechanisms of RIDD-regulated apoptosis are still unclear but recently it has been proposed that RIDD inactivates anticaspase-2 pre-miRNAs, whose cleavage leads to the generation of active caspase-2, which has a pro-apoptotic role [18].

\subsection{Pro-Apoptotic Signals Involving PERK-eIF2a-ATF4/CHOP}

Upon severe stress conditions, active PERK phosphorylates eIF2 $\alpha$, which in turn activates ATF4. The transcription factor ATF4 binds the promoter region of the CHOP gene, increasing its mRNA expression and subsequently its protein levels [21]. CHOP represents a crucial player in ER stress-mediated cell death and all three branches of UPR can affect CHOP expression [36]. During persisting ER stress, ATF4 and CHOP promote cell death by activating genes involved in protein synthesis, such as GADD34 and ERO1 $\alpha$ (endoplasmic reticulum oxireductin1 $\alpha$ ) [37]; GADD34, whose upregulation represents a pro-apoptotic mechanism depending on CHOP expression, induces the dephosphorylation of eIF $2 \alpha$ and thus restores protein synthesis, whereas ERO1 $\alpha$, which is involved in the oxidation of PDI, leads to a condition of hyper-oxidation in ER [30]. By augmenting ERO1 $\alpha$ expression, CHOP also promotes $\mathrm{Ca}^{2+}$ release via channel inositol 1,4,5-triphosphate receptor (IP3R) from ER to the cytoplasm. The increase of $\mathrm{Ca}^{2+}$ in the cytoplasm activates the calcium/calmodulin-dependent protein kinase II (CaMKII), which acts as an upstream molecule regulating apoptosis [38].

$\mathrm{CHOP}$ can definitely activate a death program inducing both extrinsic and intrinsic apoptotic pathways. CHOP up-regulates death receptor 5 (DR5) together with caspase-8 activation, which 
in turn generates the truncated form of Bid (tBid) and transports it into the mitochondria [39]. On the other hand, $\mathrm{CHOP}$ can also trigger the intrinsic apoptotic pathway, decreasing the expression of anti-apoptotic $\mathrm{Bcl}-2$ and $\mathrm{Bcl}-\mathrm{xL}$ proteins, while increasing the expression of pro-apoptotic proteins such as Bak, Bax, Bim, Puma, and Noxa [40]. Besides the interplay between ER and mitochondrial intrinsic apoptosis pathway, activation of ER-resident caspase, during ER stress, represents another mechanism to induce apoptosis. Indeed, under ER stress, the active form of rodent caspase-12 and human caspase- 4 activates caspase- 9 , which in turn activates caspase-3, triggering apoptosis [41].

\subsection{Pro-Apoptotic Signals Involving ER $\mathrm{Ca}^{2+}$ Release}

The perturbation of $\mathrm{Ca}^{2+}$ levels represents another method regulating the intrinsic apoptosis pathway involving ER. ER-associated caspase-8 cleaves BAP31, an integral ER membrane protein forming the p20 fragment, thus abolishing its pro-survival function [42]. Moreover, the p20 fragment exerts pro-apoptotic signals by releasing $\mathrm{Ca}^{2+}$ from ER into the cytosol. Once in the cytosol, $\mathrm{Ca}^{2+}$ is subsequently internalized by the mitochondria, resulting in mitochondrial fission and cytochrome $c$ release. Edelfosine, an antitumor agent, induces the cleavage of BAP31 with the formation of pro-apoptotic p20 fragment and causes a gradual $\mathrm{Ca}^{2+}$ release from ER in HeLa cells [43].

\subsection{The Role of UPR in Cancer Cells}

Numerous studies reported that UPR is often upregulated in cancer, suggesting its supportive role to tumor progression [31]. Indeed, ER stress and UPR are involved in all different stages of tumor progression. In the early stages of transformation, the high demand for proteins to sustain growth induces ER stress that in turn activates a pro-survival UPR, increasing the protein folding capacity. For example, the inhibition of IRE1 $\alpha$ RNAse activity decreases breast cancer cell growth in vitro [44]. During tumor progression, extrinsic stress factors for tumors, such as hypoxia, nutrient starvation, and high cell density, induce ER stress, and the resulting adaptative UPR can promote the expression of pro-angiogenic factors to resolve hypoxia and can rewire the metabolic pathways to increase nutrient supply. IRE-XBP1's signaling can sustain cancer growth in hypoxic condition, likely through interaction with HIF1 $\alpha$ [45]. In the metastatic stage, the epithelial to mesenchimal transition (EMT) allows for the loss of cell to cell contacts, favoring the formation of a migratory and invasive phenotype. Activation of ER stress has been described to help cancer cells in EMT by overcoming the stress of cell detachment and this involves both the IRE-XBP1s and PERK-eIF2 $\alpha$-ATF4 signaling pathways $[46,47]$. Finally, during chemotherapy, UPR is an important mechanism that can induce chemoresistance in cancer by enhancing drug efflux from the cell. It has been reported that knockdown of BiP, ATF6, ATF4, and XBP1s can resensitize cancer cells to chemotherapy [48,49]. Constitutive activation of cytoprotective UPR signaling supports cancer cell progression and chemoresistance. However, upon prolonged or severe ER stress condition, a persistent UPR can induce a pro-death program. Therefore, to obtain an antitumor activity through the ER stress modulation, two approaches can be followed: on the one hand, the adaptative UPR can be inhibited for rendering the cells intolerant to ER stress and on the other hand, a sustained ER stress, activating pro-death signaling, can be induced.

\section{Natural Compounds}

For millennia, plants represented fundamental components of human life. We use plants not only as a source for food, beverages, cosmetics, and dyes, but also as drugs in medicine. A healthy diet including the daily consumption of fruits, vegetables, and spices can be an effective way to prevent the development of cancer, on the basis of the bioactive compounds contained in these foods [50]. These molecules are also known as phytochemicals, or nutraceuticals, and can represent plant secondary metabolites. The use of natural products constitutes a promising intervention to prevent, inhibit, or reverse the process of carcinogenesis [51]. Natural compounds are characterized by antioxidant, anticarcinogenic, antimutagenic, and detoxification properties [52] that could be used to produce new drugs with effective anticancer activity. 
Although many antitumor compounds have been demonstrated, unfavorable side effects and drug resistance still represent limitations of current anticancer therapy [53]. Indeed, the side effects of traditional drugs prevent clinical outcomes. Thus, researchers need to identify new agents to develop more reliable therapies. Once the curative potential of plant-derived drugs is known, it is possible to investigate the synergistic or additive effects that result from the assortment of compounds occurring in plants [54]. In addition, the toxicity of natural compounds is usually less compared to traditional drugs. Thus, their use is supposed to expand the efficacy of traditional anticancer agents, and at the same time, to decrease their toxicity. Natural compounds and traditional agents, combined together, would potentially lower the dose of the classic drugs that is needed to obtain the therapeutic outcome, consequently limiting their detrimental effects [55]. To reach a successful anticancer treatment strategy, it is important to better clarify how the natural compounds interact with cellular targets. Hence, affecting the increase of ER stress related protein response could represent an interesting approach to modify the homeostasis of the ER in cancer cells in order to activate apoptosis. Although ER stress can promote the survival of cancer cells, under specific conditions, it can support cell death. Different natural compounds have been reported to induce ER stress-related apoptosis in malignant cells $[30,56,57]$.

In this review article, we discuss the ER stress-involving antitumor mechanisms of the most known natural compounds, and of some new natural compounds, in the most common human cancers (Figure 1).

\subsection{Role of ER Stress in Curcumin-Induced Apoptosis in Cancer}

Curcumin is a polyphenol compound extracted from the turmeric rhizome of Curcuma Longa plant, and is a yellow spice widely used in Indian cooking, textile dyes, and in traditional Ayurvedic medicine [57]. Over the past ten years, in vitro experiments have demonstrated the anticancer effects of curcumin in different cancer cell lines by inducing cell cycle arrest and apoptosis, most importantly through modulation of several distinct cancer targets [14]. Garrido-Armas et al. recently demonstrated, in A172 human glioblastoma cell line, that curcumin can cause cell death via a paraptosis pathway involving the ER. The authors observed changes in the expression of IRE1 $\alpha$ and ATF6 genes, miR27a, miR-222, and miR-449 after exposure of the cells to curcumin [58].

As discussed in different papers, curcumin can induce cancer cell death and the molecular mechanisms of curcumin-induced apoptosis in metastatic prostate cancer cells were recently investigated by Rivera et al. These authors, utilizing a gel-free shotgun quantitative proteomic analysis associated with tandem mass tag isobaric labeling-based-signaling networks, revealed that curcumin promoted ER stress-mediated apoptosis in PC3 prostate cancer cells. The mechanisms by which this compound caused cell death were associated with ROS production, autophagy, and UPR induction, in particular with increased BiP, IRE1 $\alpha$, PDI, and calreticulin expression [59]. Curcumin was also able to induce apoptosis in the WEHI-3 murine myelomonocyte leukemia cell line in a dose-dependent manner. Interestingly, curcumin increased CHOP, ATF6, IRE1, and caspase-12 expression levels. Therefore, curcumin increased ROS production and $\mathrm{Ca}^{2+}$ release in the cytosol but decreased the level of mitochondrial membrane potential [60]. Roberts et al., investigating the effects of combined treatment with curcumin and sildenafil in different gastrointestinal tumor cell lines, demonstrated, using siRNA experiments, that PERK and ATF6 are involved in curcumin combined with sildenafil cytotoxicity [61]. In LoVo and HT-29 human colorectal cancer cell lines, curcumin improves the anticancer activity of irinocan by increasing ROS production and by activating the ER stress pathway [62]. The rhizome of many Curcuma species is rich in other phenolic compounds, collectively called curcuminoids, consisting of a mixture of curcumin, demethoxycurcumin (DMC), and bisdemethoxycurcumin (BDMC). In the NCI H460 human lung cancer cell line, BDMC significantly induced apoptotic death as indicated by activation of caspase- $3,-8$, and -9 , and increased ROS levels and $\mathrm{Ca}^{2+}$ production, together with increased ER stress associated proteins such as BiP, CHOP, IRE1( $-\alpha$ and $-\beta)$, ATF6 ( $-\alpha$ and $-\beta)$, and caspase-4 [63]. In the same human lung cancer cell line, DMC was also able to promote apoptosis by activating caspase- $3,-8$, and -9 , and to promote apoptosis-inducing factor (AIF), Endo G and poly (ADP-ribose) polymerase (PARP) expression. Furthermore, its anticancer activity occurs also through 
GRP78, GADD153, IRE1 $\beta$, ATF6 ( $-\alpha$ and $-\beta)$, and caspase-4 increased expression [64]. In SW620 colon cancer cells, B63, a mono-carbonyl analogue of curcumin synthetized to increase its biological activity and bioavailability, showed significant anti-proliferative and pro-apoptotic effects by up-regulating the levels of Bad and Bim proteins and enhancing cytochrome $c$ release from mitochondria. Moreover, its anticancer activity was dependent on ER stress activation [65]. In two different human ovarian cancer cell lines (A2780 and CP70), the curcumin analogue B19 induced apoptosis that was more effective than curcumin in the activation of caspase-3. At an apoptosis-promoting concentration, B19 induced ROS production and ER stress activation; similar to curcumin, B19 acts through different molecular pathways, including ROS and ER stress [66].

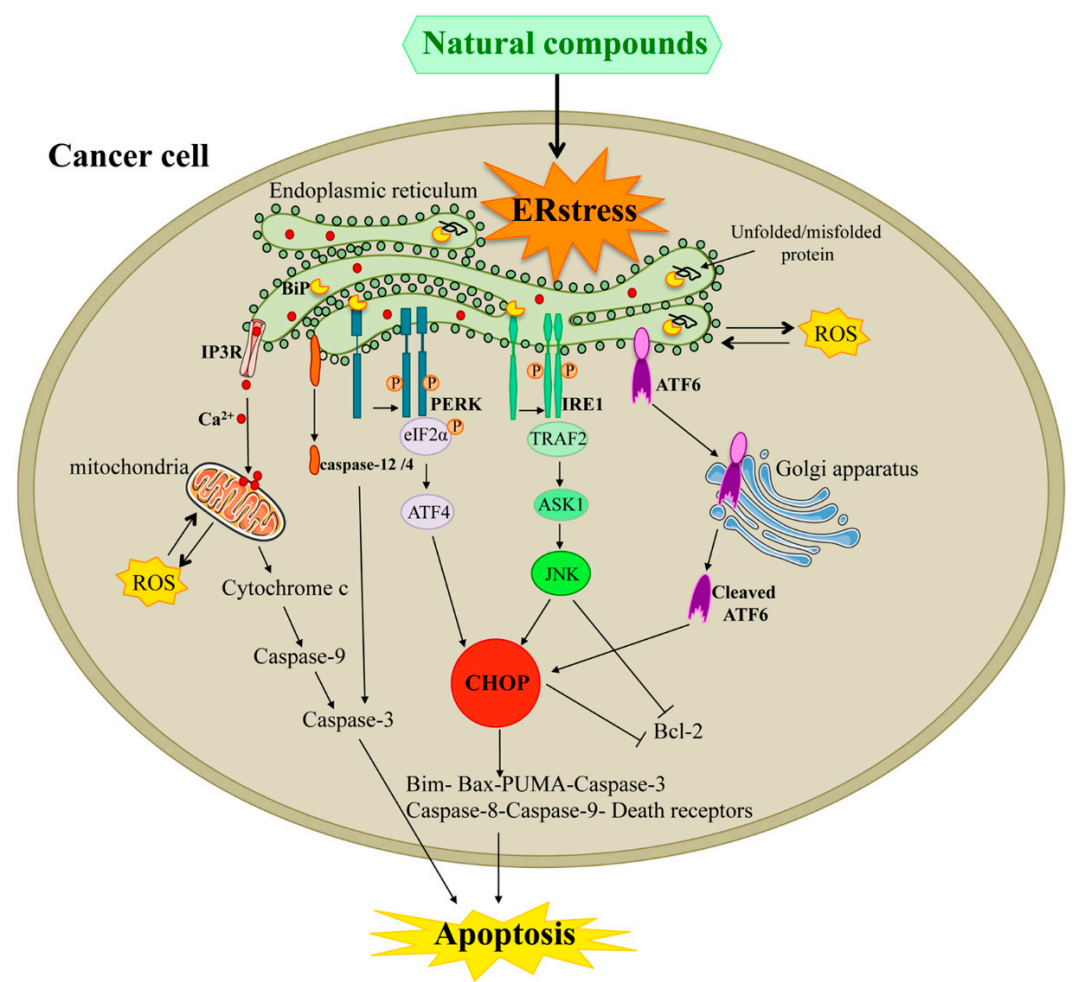

Figure 1. ER stress-related apoptosis triggered by natural compounds. If the adaptive UPR pathway is not able to restore the ER function, upon severe or prolonged ER stress, activation of ER stress sensors can lead to apoptosis. A lot of natural compounds can induce ER stress, which leads to activation of the three ER sensors. Dissociation of BiP from all three sensors PERK, IRE1, and ATF6 leads to generation of their active forms. Active PERK dimerizes, autophosphorylates, and via the eIF2 $\alpha$ /ATF4/CHOP pathway, modulates intrinsic and extrinsic apoptosis pathways. Active IRE1 has been demonstrated to induce the expression of Bcl-2 family members both via CHOP and via TRAF2/ASK1/JNK. Cleaved ATF6 can activate the induction of the pro-apoptotic transcription factor $\mathrm{CHOP}$ and consequently regulate Bcl-2 family members expression. All three branches of UPR can act concertedly to trigger both mitochondrial and death receptors apoptosis. Moreover, the $\mathrm{Ca}^{2+}$ release from ER can activate the ER-resident caspase-12/4, which in its active state, can promote the caspase-3 activation leading ultimately to apoptosis. Moreover, in ER stress conditions, oxidative stress induces the calcium leakage from ER and its subsequent uptake by the mitochondria leading to releasing cytochrome $c$ from the mitochondrial matrix. Upon ER stress conditions, $\mathrm{Ca}^{2+}$ release from ER and mitochondrial ROS production alter cellular homeostasis and trigger apoptosis. Abbreviations used in Figure 1: ASK1: apoptosis signal-regulating kinase; ATF6: activating transcription factor 6; ATF4: activating transcription factor 4; Bax: (Bcl-2)-associated X protein; Bcl-2: B-cell lynphoma2; BiP: binding immunoglobulin protein; CHOP: C/EBP homologous protein; eIF2 $\alpha$ : Eukaryotic initiation factor $2 \alpha$; ER: endoplasmic reticulum; IP3R: inositol 1,4,5,-triphosphate receptor; TRAF2: tumor necrosis factor receptor-associated factor 2; JNK: JUN N-terminal kinase; ROS: reactive oxygen species. 
In the H1975 human non-small cell lung cancer (NSCLC) cell line, gefitinib-resistant WZ35, an analog of curcumin, exerts cytotoxic effects by increasing ROS levels and by activating the ER stress pathway [67]. MTH-3, a water soluble curcuminoid derivative, has also been shown to induce intrinsic and extrinsic apoptosis pathways mediated by ER stress signals in the MDA-MB-231 human breast cancer cell line [68].

The activation of ER stress-related apoptosis in cancer cells can open the way to new therapeutic options for curcumin and its analogues in cancer therapy. The ER-stress mediated anticancer activity exerted by curcumin and its analogos is summarized in Table 1 .

Table 1. Curcumin and its analogues with ER stress-mediated anticancer activity.

\begin{tabular}{|c|c|c|c|}
\hline Compound & Tumor Type/Cell Line & ER Stress Signaling & Reference \\
\hline $\begin{array}{l}\text { Curcumin } \\
\text { (Curcuma longa) }\end{array}$ & $\begin{array}{l}\text { Human prostate cancer } \\
\text { PC3 }\end{array}$ & 个IRE1 $\alpha$; BiP; PDI; calreticulin & [59] \\
\hline $\begin{array}{l}\text { Curcumin } \\
\text { (Curcuma longa) }\end{array}$ & $\begin{array}{l}\text { Murine Myeloma } \\
\text { WEHI-3 }\end{array}$ & 个ATF6; CHOP; IRE1 $\alpha$; caspase-12 & [60] \\
\hline $\begin{array}{l}\text { Curcumin + sildenafil } \\
\text { (Curcuma longa) }\end{array}$ & $\begin{array}{l}\text { Human gastric, colon, liver cancer } \\
\text { HC116; HT29; HEPG2 }\end{array}$ & $\uparrow \mathrm{pEIF} 2 \alpha ; \mathrm{CHOP}$ & [61] \\
\hline $\begin{array}{l}\text { Curcumin + irinotecan } \\
\text { (Curcuma longa) }\end{array}$ & $\begin{array}{l}\text { Human colorectal cancer } \\
\text { HT29; LoVo }\end{array}$ & $\uparrow \mathrm{CHOP} ; \mathrm{PDI} ; \mathrm{BiP}$ & [62] \\
\hline Bisdemethoxycurcumin & $\begin{array}{l}\text { Human lung cancer } \\
\text { NCI H460 }\end{array}$ & $\begin{array}{l}\uparrow \mathrm{BiP} ; \mathrm{IRE} 1(\alpha \text { and } \beta) ; \mathrm{CHOP} \\
\text { ATF } 6(\alpha \text { and } \beta) \text {; caspase- } 4\end{array}$ & [63] \\
\hline Demetoxycurcumin & $\begin{array}{l}\text { Human lung cancer } \\
\text { NCI H460 }\end{array}$ & $\begin{array}{l}\uparrow \mathrm{BiP} ; \mathrm{IRE} 1 \beta ; \mathrm{CHOP} ; \mathrm{ATF} 6(\alpha \text { and } \\
\beta) ; \text { caspase- } 4\end{array}$ & [64] \\
\hline $\begin{array}{l}\text { B63 } \\
\text { analogue of curcumin }\end{array}$ & $\begin{array}{l}\text { Human colon cancer } \\
\text { SW620 }\end{array}$ & $\uparrow$ ER stress markers & [65] \\
\hline $\begin{array}{l}\text { B19 } \\
\text { analogue of curcumin }\end{array}$ & $\begin{array}{l}\text { Human ovarian cancer } \\
\text { A2780; CP70 }\end{array}$ & $\uparrow$ ROS; p-PERK; pEIF2 $\alpha$; CHOP & [66] \\
\hline $\begin{array}{l}\text { WZ35 } \\
\text { analogue of curcumin }\end{array}$ & $\begin{array}{l}\text { Human lung cancer } \\
\text { HI975 }\end{array}$ & $\uparrow \mathrm{pEIF} 2 \alpha ; \mathrm{ATF} 4 ; \mathrm{CHOP}$ & [67] \\
\hline $\begin{array}{l}\text { MTH-3 } \\
\text { analogue of curcumin }\end{array}$ & $\begin{array}{l}\text { Human breast cancer } \\
\text { MDA-MB-231 }\end{array}$ & $\begin{array}{l}\uparrow \mathrm{CHOP} ; \mathrm{ERO} 1 ; \mathrm{PDI} \text {; PERK; } \\
\text { calnexin } \downarrow \mathrm{BiP}\end{array}$ & [68] \\
\hline
\end{tabular}

\subsection{Role of ER Stress in Resveratrol-Induced Apoptosis in Cancer}

Resveratrol, a polyphenolic compound belonging to the class of stilbenes, is present in many plants including grape (mainly skin), blueberries, and peanut, as well as red wine [69]. It has been shown to arrest the cell cycle and to trigger apoptosis by inhibiting ERK1/2 cascade and modulating the expression of some proteins involved in DNA synthesis and the cell cycle, such as p53 and cyclin-dependent kinases [70]. Resveratrol has been found to block cancer growth by targeting different molecules and pathways involved in cancer development [70]. Recent findings demonstrate its ability to induce ER stress-related apoptosis in different cancer cell types. In human multiple myeloma cell lines, resveratrol induces ER stress-related apoptosis by inhibiting the pro-survival XBP1's function and by promoting the enrichment of its molecular target sirtuin1 [71]. In the A375SM malignant melanoma cell line, resveratrol activates apoptosis and cell cycle arrest through enhancing simultaneously ER stress and ROS production. The A375SM treatment with resveratrol induces the increase of p38, p53, and Bax expression levels and the decrease of Bcl-2 level. Resveratrol also increases the intracellular levels of ER stress-related proteins p-eIF2 $\alpha$ and CHOP [72]. In the HepG2 human hepatoblastoma cell line, resveratrol induces ER stress, increasing XBP1 splicing and CHOP expression; moreover, resveratrol intensifies palmitate-induced cell death of HepG2 cells and increases palmitate-induced ER stress. Generally, in this cell line, resveratrol promotes an amplification of palmitate toxicity primarily through ER stress-dependent apoptosis [73]. Moreover, in NCI-H460 human non-small cell lung cancer cell line, Bai et al. demonstrated a pro-apoptotic activity of resveratrol in miR-200c-positive cells. To analyze the mechanism of resveratrol in these cells, by using Target Scan, it was possible to determine the predicted target genes of miR-200c. The authors focused their attention on ER stress-related proteins, such as RECK, a membrane-bound protein, or ER stress molecules, such as $\mathrm{BiP}$ and $\mathrm{CHOP}$, which all were observed to be increased in miR-200c-transfected cells, leading to 
the conclusion that miR-200c expression sensitizes H460cells to resveratrol, mainly through RECK expression [74]. In two human nasopharyngeal carcinoma cell lines, NPC-TW076 and NPC-TW039, resveratrol induced ER stress- and autophagy-related apoptosis as revealed by the marked increase of IRE1, p-PERK, CHOP, and ATF6. Pretreatment of the cells with specific caspase-12 inhibitors but not caspase- 4 inhibitors, or silencing caspase- 4 or -12 by siRNA for $24 \mathrm{~h}$ prior to incubation of resveratrol for $24 \mathrm{~h}$, significantly reduced the activation of caspase- 3 and -9 originally induced by resveratrol. In the same study, resveratrol induced autophagy together with UPR expression and ER dilatation [75]. In human lung adenocarcinoma A549 cells, a resveratrol and arsenic trioxide combination promotes ER stress- and mitochondrial dysfunction-mediated apoptosis as manifested by the increased expression of ER stress hallmarks BiP, caspase-12, and CHOP. Moreover, these authors demonstrated that resveratrol and arsenic trioxide-induced ER stress and mitochondrial dysfunction depended on ROS production as indicated by the experiments in the presence of N-acetyl-L-cysteine (NAC), a potent ROS scavenger, that attenuated the expression of ER stress-related markers and the loss of mitochondria membrane potential [76]. Gwak et al. reported that resveratrol prompts ER stress-related apoptosis by interfering with protein glycosylation [77]. However, the use of resveratrol has been limited by its poor solubility and low bioavailability [78]. Drug resistance represents one of the main reasons of the failure of chemotherapy in different cancers, so the development of novel therapeutic strategies is highly mandatory. An effective analogue of resveratrol, (Z)3,4,5,4'-trans-tetramethoxystilbene (TMS), selectively induces cell death of gefitinib-resistant non-small cell lung cancer cells by enhancing the cytosolic $\left[\mathrm{Ca}^{2+}\right]$ levels and causing ER stress (as indicated by PERK and eIF2 $\alpha$ activation and CHOP upregulation [79]). A natural demethylated resveratrol analog from blueberries, pterostilbene, exerts anticancer ER stress-related activity in human esophageal cancer. Indeed, pterostilbene upregulates BiP, ATF6, p-PERK, p-eIF2 $\alpha$, and CHOP expression, and increases intracellular calcium levels in EC109 esophageal cancer cells. Silencing CHOP by siRNA significantly decreases the pterostilbene-induced apoptosis. Moreover, in in vivo experiments, this compound was also shown to significantly upregulate $\mathrm{BiP}$ and $\mathrm{CHOP}$ expression in EC109 xenografts. These experiments provide evidence of ER-mediated pro-apoptotic activity of pterostilbene in human esophageal cancer cells [80]. Res-006, a novel resveratrol derivative, induced cell death in human hepatoblastoma HepG2 cells by triggering ER stress and mitochondrial dysfunction, providing a rationale for the development of new resveratrol-derived molecules for cancer treatment targeting both mitochondria and ER stress [81]. The ER stress-mediated anticancer activity exerted by resveratrol and its analogos is summarized in Table 2.

Table 2. Resveratrol and its analogues with ER stress-mediated anticancer activity.

\begin{tabular}{|c|c|c|c|}
\hline Compound & Tumor Type/Cell Line & ER Stress Signaling & Reference \\
\hline Resveratrol & $\begin{array}{l}\text { Human multiple myeloma } \\
\text { ANBL-6; }\end{array}$ & $\begin{array}{l}\uparrow \mathrm{IE} 1 \alpha ; \mathrm{CHOP} ; \mathrm{JNK} \text { activation } \\
\downarrow \mathrm{XBP} 1 \mathrm{~s}\end{array}$ & [71] \\
\hline Resveratrol & $\begin{array}{l}\text { Human melanoma } \\
\text { A375SM }\end{array}$ & $\uparrow \mathrm{pEIF} 2 \alpha ; \mathrm{CHOP}$ & [72] \\
\hline Resveratrol + palmitate & $\begin{array}{l}\text { Human hepatoblastoma } \\
\text { HepG2 }\end{array}$ & $\uparrow \mathrm{ATF} 4 ; \mathrm{CHOP}$ & [73] \\
\hline Resveratrol & $\begin{array}{l}\text { Human lung cancer } \\
\text { NCI-H460 }\end{array}$ & $\uparrow \mathrm{CHOP} ; \mathrm{BiP}$ & [74] \\
\hline Resveratrol & $\begin{array}{l}\text { Human nasopharyngeal cancer } \\
\text { NPC-TW076; NPC-TW039 }\end{array}$ & $\uparrow$ IRE $1 \alpha$; CHOP; ATF $6 \alpha$; p-PERK & [75] \\
\hline Resveratrol & $\begin{array}{l}\text { Human ovarian cancer } \\
\text { Pa-1; MDAH2774; SKOV3 }\end{array}$ & $\uparrow$ PERK;CHOP; IRE $1 \alpha ;$ ATF6 $\alpha$; BiP & [77] \\
\hline $\begin{array}{l}\text { Resveratrol + arsenic } \\
\text { trioxide }\end{array}$ & $\begin{array}{l}\text { Human lung cancer } \\
\text { A549 }\end{array}$ & $\uparrow \mathrm{BiP} ; \mathrm{CHOP}$; caspase-12 & [76] \\
\hline $\begin{array}{l}\text { RES006 } \\
\text { Resveratrol analog }\end{array}$ & $\begin{array}{l}\text { Human hepatoblastoma } \\
\text { HepG2 }\end{array}$ & $\uparrow \mathrm{pEIF} 2 \alpha ; \mathrm{ATF} 4 ; \mathrm{CHOP}$ & [81] \\
\hline $\begin{array}{l}\text { TMS } \\
\text { Resveratrol analog }\end{array}$ & $\begin{array}{l}\text { Human lung cancer } \\
\text { A579; H1975 }\end{array}$ & $\begin{array}{l}\uparrow \text { pEIF2 } \alpha ; \text { p-PERK CHOP; IRE1 } \alpha ; \\
\text { p-JNK }\end{array}$ & [79] \\
\hline
\end{tabular}




\subsection{Role of ER Stress in Green Tea Polyphenols-Induced Apoptosis in Cancer}

Green tea extracts (GTE) possess antitumor activity mainly due to the presence of flavan-3-ols, specifically epigallocatechin gallate (EGCG). EGCG decreases cell viability and promotes cell death in many cancer cell lines. While the mechanism of action of GTE has been examined in vitro and in vivo, the molecular targets of green tea catechins remain to be clarified. Findings from the literature indicated that GTE flavan-3-ols target ER function [82].

A GTE extract, Polyphenon $E^{\circledR}$, caused severe and prolonged ER stress in human prostate cancer cells PC3 by activating the PERK signaling arm, as demonstrated by prolonged activation of p-eIF2 $\alpha$ and ATF4 [83]. A significant activation of XBP1 mRNA splicing has also been observed in these cells, indicating an involvement of both IRE1 $\alpha$ and ATF6 signaling arms of ER stress in the cellular response to Polyphenon $\mathrm{E}^{\circledR}$ [84]. XBP1s is generated by an unconventional splicing reaction upon disruption of ER homeostasis and is a marker of ER stress activation contributing to upregulation of CHOP [85]. Polyphenon $\mathrm{E}^{\circledR}$ would seem to resensitize cells to chemotherapy compounds, mainly through the increase of the expression of the pro death protein CHOP. This event seems very important in prostate cancer cells, which are more susceptible to ER stress, probably because of the remarkable demand of protein translation and processing, which certainly goes beyond the capacity of cellular folding proteins. [84]. In MM98 malignant mesothelioma cell line, EGCG induces an acute increase of BiP, XBP1, CHOP, and ATF4 with simultaneous activation of caspase-3 and -8 [86]. Among a panel of different ECG and EGCG analogues, JP8 emerged as the most potent autophagy-inducer in B16 melanoma cells. In this cell line, JP8 reduced cell viability and increased apoptosis more effectively than in normal mouse AML-12 hepatocyte cells. Treatment with ATG5 siRNA diminished JP8-induced cell death and in these conditions also stress response proteins such as IRE1 $\alpha, \mathrm{CHOP}, \mathrm{p}$-eIF $2 \alpha$ were downregulated [87].

The ER-stress mediated anticancer activity exerted by green tea polyphenols and its analogos is summarized in Table 3.

Table 3. Green tea polyphenols and its analogues with ER stress-mediated anticancer activity.

\begin{tabular}{lllc}
\hline \multicolumn{1}{c}{ Compound } & Tumor Type/Cell Line & ER Stress Signaling & Reference \\
\hline Polyphenon E $^{\circledR}$ & $\begin{array}{l}\text { Human prostate cancer } \\
\text { PC3 }\end{array}$ & $\uparrow$ CHOP & [84] \\
\hline EGCG & $\begin{array}{l}\text { Human mesothelioma } \\
\text { MM98 }\end{array}$ & $\begin{array}{l}\uparrow \mathrm{BiP} ; \mathrm{CHOP} ; \text { ATF4; } \\
\text { XBP1 }\end{array}$ & {$[86]$} \\
\hline JP8 & Melanoma & $\uparrow$ ATF4; CHOP & {$[87]$} \\
EGCG analog & B16 & & \\
\hline EGCG & Human bladder carcinoma & $\uparrow$ Binding to BiP & {$[88]$} \\
& T24/83 & & \\
\hline
\end{tabular}

$\uparrow$-increasing concentration.

\subsection{Role of ER stress in Tocotrienols-Induced Apoptosis in Cancer}

Vitamin E comprises two groups of compounds: $\alpha-, \beta-, \gamma_{-}^{-}$, and $\delta$-tocopherols (TPs), and the corresponding unsaturated tocotrienols (TTs). $\alpha$-Tocopheryl succinate, a derivative of $\alpha$-tocopherol, induces apoptosis in SGC-7901 human gastric cell line increasing the expression of the main ER stress-associated molecules, $\mathrm{BiP}, \mathrm{CHOP}$, and caspase-4. Moreover, in the presence of antioxidant NAC, the mRNA and protein expression of BIP and CHOP was inhibited, indicating that in SGC-7901 cells, $\alpha$-tocopheryl succinate induced ER stress through ROS production [89]. The other component of vitamin $\mathrm{E}$ is represented by TTs. TTs are present in different natural sources such as red palm oil, annatto seeds, and rice bran. Recently, TTs (specifically, $\gamma$-TT and $\delta$-TT) have sparked interest due to their health-related activities in chronic pathologies based on their antioxidant, neuroprotective, cholesterol-lowering, and anti-inflammatory roles. Several in vitro and in vivo studies highlighted 
the antitumor effects of TTs in many types of cancer cells. Especially, TTs were shown to exert anti-proliferative/pro-apoptotic effects, to affect cancer stem cell subpopulation [90], and to decrease the metastatic or angiogenic abilities of different cancer cells [91]. In malignant +SA mammary epithelial cell lines, $\gamma$-TT-induced apoptosis is mediated by the PERK/eIF1 $\alpha /$ ATF4 ER stress response pathway and by the increased expression of the pro-apoptotic protein CHOP and TRB3 [92]. Another study, focusing on the molecular mechanisms of anticancer activity of $\gamma$-TT in breast cancer cell lines, showed that in MDA-MB-231 and MCF-7 cells, $\gamma$-TT induced apoptosis, at least in part, mediated by ER stress. In these cells, ER stress induction of JNK and p38 MAPK followed by up-regulation of DR5 in a CHOP-dependent manner was demonstrated to be involved in $\gamma$-TT-prompted apoptosis [93]. Patacsil et al. demonstrated that, in the MDA-MB-231 and MCF-7 breast cancer cell lines, $\gamma$-TT induced ER stress-mediated apoptosis as demonstrated by gene expression microarray analysis. Indeed, microarray analysis highlighted the modulation of genes involved in the ER stress response, such as ATF3, a target gene for ATF4; the authors demonstrated that ATF3 had a crucial role in $\gamma$-TT-induced apoptosis in MCF-7 cells. Moreover, an up-regulation of the ER stress-related protein markers BiP, ATF4, PERK, and IRE1 $\alpha$ was observed in both MDA-MB-231 and MCF-7 cells treated with $\gamma$-TT [94]. In these cell lines, the cytotoxic activity of $\gamma$-TT was associated with the concerted induction of autophagy and ER stress-mediated apoptosis, since $\gamma$-TT also activated LC3-I conjugation to ATG5-ATG12 and the conversion of LC3-I in to its lipidated and autophagosome-bound form LC3-II [95].

Comitato et al. demonstrated that, in the HeLa human cervical cancer cell line, and in the MCF-7 human breast cancer cell line, $\gamma$ - and $\delta$-TT induced apoptosis by triggering signals originating from ER stress. Indeed, after TTs treatment the expression of p-IRE1 $\alpha$, XBP-1, and CHOP was increased. $\gamma$ and $\delta$-TT induced the expression of caspase- 12 in HeLa cells treated with $\delta$-TT, and this activation was associated with caspase-9 cleavage [96].

The role of $\delta$-TT was investigated by Montagnani Marelli et al. in two different human melanoma cell lines, BLM and A375, using in vitro and in vivo experiments. The authors found that $\delta$-TT exerts a significant anti-proliferative/pro-apoptotic effect on both cell lines but not on normal melanocytes, demonstrating that, in both cell lines, $\delta$-TT induced the expression of different ER stress markers such as BiP PERK, IRE1 $\alpha$, p-EIF2 $\alpha$, ATF4, and CHOP. The cleavage of caspase- 4 was also triggered by $\delta$-TT in both melanoma cell lines. In the presence of ER stress inhibitors the pro-apoptotic activity of $\delta$-TT was in part counteracted, underlying the fact that the ER stress pathways could represent a relevant target for melanoma treatment [97]. The ER-stress mediated anticancer activity exerted by tocotrienols is summarized in Table 4.

Table 4. Tocotrienols with ER stress-mediated anticancer activity.

\begin{tabular}{|c|c|c|c|}
\hline Compound & Tumor Type/Cell Line & ER Stress Signaling & Reference \\
\hline$\alpha$-Tocopheryl succinate & $\begin{array}{l}\text { Human gastric cancer } \\
\text { SGC-7901 }\end{array}$ & 个 BiP; CHOP; caspase-4; & [89] \\
\hline$\gamma$-tocotrienol & $\begin{array}{l}\text { Malignant +SA mammary } \\
\text { epithelial cell line }\end{array}$ & $\begin{array}{l}\uparrow \text { p-PERK; p-EIF2 } \alpha ; \text { ATF } 4 \\
\text { CHOP }\end{array}$ & [92] \\
\hline$\gamma$-tocotrienol & $\begin{array}{l}\text { Human breast cancer } \\
\text { MDA-MB-231 }\end{array}$ & 个 BiP; ATF4; CHOP; XBP1 & [93] \\
\hline$\gamma$-tocotrienol & $\begin{array}{l}\text { Human breast cancer } \\
\text { MCF-7; MDA-MB-231 }\end{array}$ & 个 PERK; p-EIF $2 \alpha$; ATF4; CHOP & [94] \\
\hline$\gamma$-tocotrienol & $\begin{array}{l}\text { Human breast cancer } \\
\text { MCF-7; MDA-MB-231; MCF10A }\end{array}$ & $\begin{array}{l}\uparrow \text { p-PERK; p-EIF2 } \alpha \text {; ATF4; } \\
\text { CHOP; TRB3 }\end{array}$ & [95] \\
\hline $\begin{array}{l}\gamma \text {-tocotrienol } \\
\delta \text {-tocotrienol }\end{array}$ & $\begin{array}{l}\text { Human cervical and breast cancer } \\
\text { HeLa; MCF-7 }\end{array}$ & $\begin{array}{l}\uparrow \mathrm{p}-\mathrm{IRE} 1 \alpha ; \mathrm{XBP} 1 \mathrm{~s} ; \mathrm{CHOP} ; \\
\text { caspase-12 }\end{array}$ & [96] \\
\hline$\delta$-tocotrienol & $\begin{array}{l}\text { Human melanoma } \\
\text { BLM; A375 }\end{array}$ & $\begin{array}{l}\uparrow \mathrm{BiP} ; \mathrm{CHOP} ; \text { PERK; IRE } 1 \alpha ; \\
\text { p-EIF } 2 \alpha \text {; ATF } 4 \text {; CHOP; caspase- } 4\end{array}$ & [97] \\
\hline
\end{tabular}




\subsection{Role of ER Stress in Garcinia-Induced Apoptosis in Cancer}

Mangosteen (Garcinia mangostana L.) is a fruit used as a traditional herbal medicine in Southeast Asia for the treatment of inflammation, amenorrhea, and abdominal pain [98], which contains various xanthones including $\alpha$-mangostin, $\gamma$-mangostin, and garcinone $E$ with antitumor effects in different cancer cell lines [99]. Sato et al. primarily hypothesized that the pro-apoptotic activity of $\alpha$-mangostin was related to the ER stress pathway in PC12 cells. As with thapsigargin, $\alpha$-mangostin induced apoptosis via sarcoplasmic/endoplasmic $\mathrm{Ca}^{2+}$ ATPase (SERCA) inhibition [100]. In the LNCaP and 22RV1 human prostate cancer cell lines, a mangosteen fruit extract (MFE) induced an increased expression of ER stress markers such as PERK, CHOP, IRE1 $\alpha$, BiP, and cleaved caspase- 4 . At the same time, calnexin, an ER membrane protein guaranteeing accurate protein folding and quality control, was reduced. On the other hand, in normal prostate epithelial cells, MFE exerted an opposite effect by reducing PERK expression, indicating that this extract selectively targets prostate cancer cells. This ER stress induction correlates with increased apoptotic death [101]. In a subsequent paper, the same authors surprisingly observed that after CHOP silencing, $\alpha$-mangostin-treated 22RV1 cells showed significantly increased cleaved caspase-3 expression. The effect was not observed in LNCaP cells [102]. Another xanthone present in mangosteen fruit, Garcinone E, was able to reduce the proliferation of ovarian cancer cells by triggering ER stress and significantly enhancing the protein expression levels of IRE- $1 \alpha, \mathrm{XBP}-1, \mathrm{BiP}, \mathrm{CHOP}$, and caspase-12. It also exerted anti-migratory and anti-invasion effects, resulting in becoming a potential future candidate as an anti-ovarian cancer compound [103]. Gartanin, a polyphenolic xantone isolated from mangosteen fruit, has been shown to exert antitumor activities in different human malignant cells [104]. Li et al. demonstrated that gartanin activates an apoptotic pathway by modulating the expression of ER stress chaperons and markers in the 22RV1 and LNCaP human prostate cancer cell lines. For the first time, these authors provided evidence suggesting that degradation of androgen receptor $(A R)$ is regulated by the ER stress pathway. CHOP knockdown, indeed, partly reversed the gartanin-induced reduction in AR protein expression, suggesting a possible interplay between UPR activation and AR signaling [105]. Garcinol, a polyisoprenylated benzophenone, derived from Garcinia indica exerts antitumor activity in various cancer cells [106]. In Hep3B cells, garcinol induced ROS generation and increased the levels of CHOP; these changes resulted in downstream apoptosis activation with an increase of the $\mathrm{Bax} / \mathrm{Bcl}-2$ ratio; a decrease of the mitochondrial membrane potential; the release of cytochrome $c$; and the activation of caspase-9, caspase-3, and their target PARP [106]. Gambogic acid (GA) represents the main active compound of Garcinia hanburyi, possessing potent antitumor activity in a broad range of human cancers [107,108]. GA has been shown to induce apoptosis through ER stress activation in the HeLa human cervical carcinoma cell line. GA was able to induce XBP1 splicing and to up-regulate BiP, CHOP, and GADD34 mRNAs. GA induced the ER-related apoptosis pathway through up-regulation of JNK and down-regulation of ERK in HeLa cells [109]. The ER-stress mediated anticancer activity exerted by Garcinia derivates is summarized in Table 5.

Table 5. Garcinia derivatives with ER stress-mediated anticancer activity.

\begin{tabular}{lllc}
\hline Compound & Tumor Type /Cell Line & ER Stress Signalling & Reference \\
\hline$\alpha$-Mangosteen & Pheochromocytoma & $\downarrow$ Ca2+ ATPase activity; $\uparrow$ JNK & [100] \\
& PC12 & & \\
\hline Mangosteen fruit extract & Human prostate cancer & $\begin{array}{l}\uparrow \text { BiP; PERK; IRE1 } \alpha \text { calnexin } \\
\text { CHOP; caspase-4 }\end{array}$ & [102] \\
& LNCaP; 22RV1 & $\begin{array}{l}\uparrow \text { BiP; IRE1 } \alpha ; \text { XBP1; CHOP; } \\
\text { caspase-12 }\end{array}$ & [103] \\
\hline Garcinone-E & Human ovarian cancer & $\uparrow$ CHOP & [105] \\
\hline HEY; A2780 & Human prostate cancer & & [106] \\
\hline LNCaP; 22RV1 & Human hepatocellular carcinoma & $\uparrow$ CHOP & [109] \\
\hline Gambogic acid & Hep3B & & \\
\hline
\end{tabular}




\subsection{Role of ER Stress in Other Natural Compound-Induced Apoptosis in Cancer}

Recent papers published in 2018 highlighted the relevance of ER stress in the pro-apoptotic cell death pathway induced by different plan-derived natural compounds in various human cancers.

In human breast cancer cell lines, MCF-7 and MDA-MB 231, pimpinelol, a linear sequiterpene lactone from Pimpinella haussknechtii, has been shown to induce apoptosis by increasing protein aggregation and ER stress, as demonstrated by fluorescence microscopy analysis and by mRNA expression of ATF4, CHOP, GADD34, and tribbles-related protein 3 (TRIB3) [110].

Pristimerin is a naturally occurring triterpenoid displaying anti-proliferative effects in different cancer cells [111]. In order to define the mechanisms of action correlated to its antitumor activity, Cevatemre et al. observed an extensive cytoplasmic vacuolation, ER stress induction, and block of autophagic flux in MCF-7 breast cancer cells treated with pristimerin, providing new insights into the mechanisms underlying the activity of pristimerin in breast cancer care [111].

Cnidium officinale Makino (COM) has been used as a traditional medicine for thousands of years in Korea, China, and Japan for resolving blood stasis, contusions, and infertility. More recently, COM has been shown to exert antitumor activity in liver, colorectal, and oral cancer. Using Western blot analysis, it has been demonstrated that ER stress-related proteins, such as p-PERK, p-eIF- $2 \alpha$, and ATF4, were modified in apoptotic cancer cells treated with COM. This suggests that ER stress-related proteins play a role in COM-induced cell death. [56].

Although Salvia miltiorrhiza (SM) has been reported to have antitumor effects, such as apoptosis induction through caspase activation, cell cycle arrest, anti-angiogenic effect, and Bcl-2 family regulation, the molecular mechanisms of its apoptotic activity need to be demonstrated. Kim et al., in a recent study, showed the activation of ER stress-related apoptosis via miR-216b by the ethanol extract of SM. They suggested that SM induces ER stress by producing ROS and that the activated CHOP expression is followed by an increased miR-216b expression in human multiple myeloma cells (U266 and U937). In addition, SM reduces c-Jun protein expression, which is a target of miR-216b, correlated to the induction of the cleavage of caspase-3 and PARP [112].

Protodioscin (PD) represents the principal steroidal saponin in Dioscoreae rhizome exhibiting antitumor effects in several types of human cancer cells [113]. Lin et al., studying the molecular mechanisms associated with PD antitumor activity in human cervical cancer cells, have recently suggested the involvement of mitochondrial dysfunction and BiP/eIF2 $\alpha /$ ATF4/CHOP ER stress branch activation. In their study, the authors demonstrated that the silencing of BiP and CHOP by siRNA reversed the augmented ER stress-related protein expression by PD and reduced ER stress-induced apoptosis in cervical cancer cells [114].

Regarding pancreatic cancer cells, by analyzing the anti-cancer effects of Peonia suffruticosa (PS) aqueous extract, the researchers found an increased activity of caspase- $8,-9$, and -3 , and inhibition of proteasome activity. They also demonstrated a weak upregulation of death-associated protein kinase 3, an upstream ER stress-responsive integrator of apoptosis and autophagy, suggesting a partial implication of ER stress in PS anticancer activity [115].

The mechanism of the anticancer effects of a leaf methanol extract of Clinacanthus nutans, a plant with cytotoxicity against leukemia cells, was evaluated in the human SUP-T1 lymphoma cell line. This extract was able to decrease the mitochondria membrane potential, to induce annexin $V$ overexpression, ROS production, calcium release, and IRE $1 \alpha$ and CHOP protein overexpression, indicating that ER stress is one of the pathways involved in the apoptotic cell death of Clinacanthus nutans [116].

Chrysophanol, an anthraquinone whose antitumor effects have been shown in many in vitro and in vivo studies [117], has been reported to induce apoptosis in MCF-7 and BT-474 breast cancer cells as indicated by DNA fragmentation. Moreover, in these cell lines, chrysophanol induced ROS production and PERK, eIF2 $\alpha$, IRE1 $\alpha$, and CHOP protein expression. Co-treatment of cells with chrysophanol and NAC reduced the ER stress-related protein expression, indicating that ROS production and ER stress are important pathways in pro-apoptotic chrysophanol activity in breast cancer cells [118]. Many studies analyzed the anticancer activity of garlic and garlic-based extracts. In MDA-MB-231 human breast cancer 
cells and in WHCO1 human esophageal-cancer cells, the pro-apoptotic activity of ajoene, an allylsulfur compound found in garlic, was associated to its ability to induce an ER accumulation of misfolded proteins and to activate UPR. Using a fluorescently ajoene analogue, the authors demonstrated that this compound targets and accumulates in ER and increases the levels of BiP [119]. Moreover, the same authors demonstrated that in WHCO1 cells, the cytotoxic activity of the ajoene analogue BisPMB depends on increased CHOP expression [120]. Petrovic et al. investigated the molecular mechanism associated with the anticancer activity of ethanol-based garlic extract (GE) in different mammalian cancer cell lines. Using a multiplexed inhibitor bead (MIB) assay, significant changes in GE-treated versus control cells were found for 1000 proteins, and successive KEGG analysis of these proteins indicated that after GE treatment, proteins involved in the ER response were changed. Therefore, in agreement with other studies, GE activates apoptosis in many human cancer cells via ER stress and ROS regulation [121].

The antitumor activity of 7-acetylsinumaximol B (7-AB), isolated from soft coral Sinularia sandensis, was evaluated in the NCI-N87 human gastric cell line. 7-AB-treated cells exhibited increased Bad, Bim, Bax, cytochrome $c$, and cleaved caspase- 9 and -3 expression levels, suggesting that the apoptotic intrinsic pathway was activated in the 7-AB-induced cell death. Western blot analysis showed increased expression of p-PERK, p-eIF2 $\alpha$, ATF4, CHOP, and p-ATF2 proteins in 7-AB-treated cells. These results indicated that the 7-AB pro-apoptotic activity is partially mediated by the PERK/p-eIF2 $\alpha /$ ATF4 / CHOP ER stress pathway [122]. 4-nerolidylcatechol, a compound extracted from Pothomorphe umbellata L., has been shown to induce apoptosis via ER stress, both in SK-MEL-28 N and in BRAi/MEKi resistant melanoma cells [123]. Moreover, the role of the monomers PP-22, isolated from Paris polyphilla, was investigated on apoptosis and autophagy in nasopharyngeal carcinoma cell line. It has been demonstrated that PP-22 up-regulates PERK, BiP, PDI, ERO1 $\alpha$, IRE, and CHOP proteins, and induces apoptosis via mitochondrial and p38MAPK pathways. Moreover, PP-22 triggered autophagy by inhibiting the ERK signaling pathway in CNE-2 cells [124]. A list of the natural compounds discussed in this section is summarized in Table 6 .

Table 6. List of different natural compounds, published in 2018, with ER stress-mediated anticancer activity.

\begin{tabular}{|c|c|c|c|}
\hline Compound & Tumor Type /Cell Line & ER Stress Signaling & Reference \\
\hline $\begin{array}{l}\text { Pimpinelol } \\
\text { (Pimpinella haussknechtii) }\end{array}$ & $\begin{array}{l}\text { Human breast cancer } \\
\text { MCF-7 }\end{array}$ & 个ATF4; CHOP; GADD34; TRIB3 & [110] \\
\hline $\begin{array}{l}\text { Pristimerin } \\
\text { (Maytenus } s p \text { ) }\end{array}$ & $\begin{array}{l}\text { Human breast cancer } \\
\text { MCF-7 }\end{array}$ & $\uparrow$ ATF 4 ; CHOP; IRE $1 \alpha ;$ pEIF $2 \alpha$ & [111] \\
\hline Cnidium officinale Makino & $\begin{array}{l}\text { Human myeloid lymphoma } \\
\text { U937; U266 }\end{array}$ & $\uparrow$ p-PERK; pEIF2 $\alpha$; ATF4; CHOP & [56] \\
\hline Salvia Miltiorrhiza & $\begin{array}{l}\text { Human myeloid lymphoma } \\
\text { U937; U266 }\end{array}$ & $\uparrow \mathrm{p}$-PERK; pEIF2 $\alpha$, ATF4; CHOP & [112] \\
\hline $\begin{array}{l}\text { Protodioscin } \\
\text { (Dioscoreae rhizome) }\end{array}$ & $\begin{array}{l}\text { Human cervical cancer } \\
\text { HeLa; C33A }\end{array}$ & $\begin{array}{l}\uparrow \text { BiP; p-PERK; pEIF2 } \alpha, \text { ATF } 4 \\
\text { CHOP; JNK }\end{array}$ & [114] \\
\hline Paenia suffruticosa & $\begin{array}{l}\text { Human pancreatic cancer } \\
\text { PANC1; AsPC1; BxPC3 }\end{array}$ & $\uparrow \mathrm{DAPK} 3$ & [115] \\
\hline Clinacanthus nutans & $\begin{array}{l}\text { Human lymphoma and leukemia } \\
\text { SUP-T1; MOLT-4 }\end{array}$ & $\uparrow \operatorname{IRE} 1 \alpha$; CHOP & [116] \\
\hline Chrysophanol & $\begin{array}{l}\text { Human breast cancer } \\
\text { MCF-7; BT-474 }\end{array}$ & $\uparrow$ ROS; p-PERK; pEIF2 $\alpha$; CHOP & [118] \\
\hline Garlic extract & $\begin{array}{l}\text { Human multiple myeloma and human } \\
\text { prostate cancer } \\
\text { RPMI-8226; DU145 }\end{array}$ & 个 BiP; MAPK kinases; RBX1; SKP1 & [121] \\
\hline $\begin{array}{l}\text { Ajoene } \\
\text { (allyl sulfur compound } \\
\text { from garlic) }\end{array}$ & $\begin{array}{l}\text { Human breast cancer and human } \\
\text { esophageal cancer } \\
\text { MDA-MB-231; WHC1O }\end{array}$ & $\uparrow \mathrm{BiP} ; \mathrm{CHOP}$ & [120] \\
\hline $\begin{array}{l}\text { 7-Acetylsinumaximol B } \\
\text { (Sinularia sandensis) }\end{array}$ & $\begin{array}{l}\text { Human gastric cancer } \\
\text { NCI-N87 }\end{array}$ & $\begin{array}{l}\uparrow \text { p-PERK; pEIF2 } \alpha ; \text { ATF } 4 \text {; CHOP; } \\
\text { p-ATF6 }\end{array}$ & [122] \\
\hline $\begin{array}{l}\text { 4-nerolidylcatechol } \\
\text { (Pothomorphe umbellata L) }\end{array}$ & $\begin{array}{l}\text { Human melanoma } \\
\text { SK-MEL-28; } \\
\text { BRAi/MEKi SK-MEL-28 }\end{array}$ & $\uparrow \mathrm{p}$-PERK; IRE1 $\alpha$; BiP; ATF4; CHOP & [123] \\
\hline $\begin{array}{l}\text { PP-22 } \\
\text { (Paris polyphilla) }\end{array}$ & $\begin{array}{l}\text { Human nasopharyngeal carcinoma } \\
\text { CNE-2 }\end{array}$ & $\begin{array}{l}\uparrow \text { PERK; CHOP; BiP; PDI; ERO-LA; } \\
\text { IRE-LA }\end{array}$ & [124] \\
\hline
\end{tabular}




\section{Conclusions}

Cancer is one of the prevalent causes of death in the world today. In recent decades, although significant advances have been achieved in cancer therapy, such as chemotherapy, targeted therapy, radiotherapy, surgery, and immunotherapy, these conventional therapeutic approaches are characterized by awful side effects and the development of resistance [125-128]. Consequently, one of the major purposes for cancer care is to discover innovative therapeutic approaches that are able to selectively destroy malignant cells without damaging normal cells, and to diminish chemotherapy resistance $[129,130]$. In cancer cells, different conditions, such as hypoxia and lack of glucose, can lead to ER perturbation with an impact on protein folding in the ER, resulting in the accumulation of unfolded proteins, known as ER stress [3,31]. In response to ER stress, cells in the beginning activate an adaptive signaling pathway, called the unfolded protein response, to overwhelm stress and re-establish ER homeostasis [3]. On the other hand, unresolved severe ER stress can lead to the activation of both pathways of apoptosis. Clarifying the mechanisms originated by the different ER stress pathways with the purpose to endorse cell death or cell survival induction represents a significant issue in this field and will support the researchers in the development of new effective drugs for innovative anticancer therapeutic strategies. Natural compounds not only prompt apoptosis but are also able to reduce the resistance to chemotherapy via modulation of the ER stress pathways. Although numerous studies have demonstrated that plant-derived natural compounds exert their anticancer activity by inducing a chronic ER stress, some authors have pointed out that some natural molecules exhibit antitumor activity by inhibiting ER stress-related proteins to reduce adaptative UPR. About this, it has recently been shown that an ethyl acetate extract from Scindapsus cf. hederaceus (SH-EAE), by decreasing the expression of PERK and IRE1 $\alpha$, exerts anti-proliferative and anti-migratory activities in human lung cancer cells; moreover experiments in zebrafish demonstrated that a decreased expression of PERK and IRE1 $\alpha$ in SH-EAE-treated lung cancer cells is accompanied by the reduction of vessels development, suggesting an antiangiogenic effect [131]. The expression of ER stress sensor BiP may be enhanced in metastatic cells, and BiP could represent an advantageous therapeutic target [132]. Although knockdown of BiP by siRNA increases cell death in vitro [133], this may be difficult to reach in vivo and alternative approaches aimed at inhibiting GRP78 may be more effective as therapeutic strategies. In MDA-MB-231 and T-47 human breast cancer cells, EGCG is able to block the ATPase domain of BiP, suppressing its anti-apoptotic function, and sensitizes these cells to etoposide-induced caspase-7 activation and apoptosis [134]. The ER stress-mediated antitumor activity exerted by a great number of natural compounds has been demonstrated in many in vitro studies, as reported in this review, and the cytotoxic effects of these molecules have also been confirmed by in vivo studies. Recently, some studies investigated the relationship between antitumor activity of natural compounds and the ER stress modulation also in in vivo models. Chen et al. found that isoalantolactone, an active sequiterpene naturally present in many vegetables and medicinal plants, induces apoptosis in PC3 and DU145 prostate cancer cells via ROS production and ER stress activation. In vivo, isoalantolactone inhibits DU145 xenograft tumor growth and weight and increases the expression of CHOP in tumor tissue lysates [135]. Betulinic acid, a triterpenoid isolated from Betula pubescens, enhances taxol chemosensitivity in breast cancer xenografts; the immunohistochemistry assay revealed that betulinic acid up-regulates the expression of $\mathrm{BiP}$ and $\mathrm{CHOP}$, both alone or combined with taxol, confirming the results obtained in vitro [136].

As mentioned, natural compounds provide an important role in anticancer therapy [137-141]. Several epidemiologic studies have highlighted how consumption of plant-based foods, rich in phytochemicals, such as curcumin, resveratrol, and EGCG, are associated with a lower risk of many chronic diseases, including cancer [141,142]. In this review, we presented different studies that suggest how natural compounds can constitute an important arsenal of chemical molecules able to modulate ER stress (both as ER stress inducers and attenuators) to induce cancer cell death. Since the dual role of UPR in tumor progression is well established, it is crucial to understand how and when its modulation can change the balance between pro-survival and pro-death pathways; it has been shown that natural compounds can lead to death both by blocking the adaptive UPR and by promoting 
sustained ER stress; therefore, since the UPR signaling is a dynamic event, when we examine the ability of natural compounds to modulate ER stress, it is very important to consider the timing and the doses of treatment to be sure to obtain the desired cytotoxic effect.

Nevertheless, further studies are required to better define the molecular mechanisms associated with the anticancer activity of natural compounds in order to convert them to potential effective anticancer drugs.

Author Contributions: All authors discussed the results and revised the manuscript. R.M.M. and P.L. contributed to important revising; M.M.M. collected the data and wrote the manuscript.

Funding: This research was funded by PRIN-Progetti di ricerca di interesse nazionale 2015, project number 2015B7M39T_004(P.L.); Italian Ministry of University and Research (MIUR)-project Departments of excellence Department of Pharmacological and Biomolecular Sciences, Università degli Studi di Milano; and Fondazione Banca del Monte di Lombardia (R.M.M).

Conflicts of Interest: The authors declare no conflicts of interest.

\section{Abbreviations}

7-AB Acetylsinumaximol B (7-AB)

AR Androgen receptor

ASK Apoptosis signal-regulating kinase

ATF6 Activating transcription factor 6

ATF4 Activating transcription factor 4

BiP Binding immunoglobulin protein

BDMC Bisdemethoxycurcumin

CaMKII Calcium/calmodulin-dependent protein kinase II

C/EBP CCAAT/enhancer binding protein family

CHOP C/EBP homologous protein

COM Cnidium officinale Makino

DMC Demethoxycurcumin

GADD34 Growth arrest and DNA-damage-inducible protein 34

GRP78 Glucose-regulated protein 78

eIF2 $\alpha \quad$ Eukaryotic initiation factor $2 \alpha$

EGCG Epigallocatechin gallate

EMT Epithelial to mesenchimal transition

ER Endoplasmic reticulum

ERAD ER-associated degradation

ERO1 $\alpha \quad$ Endoplasmic reticulum oxireductin $1 \alpha$

ERSE ER stress response elements

GA Gambogic acid

GE Garlic extract

IP3 Inositol 1,4,5,-triphosphate

IP3R Inositol 1,4,5,-triphosphate receptor

IRE1 Inositol requiring enzyme1

JNK JUN N-terminal kinase

MFE Mangosteen fruit extract

PERK Protein kinase RNA(PKR)-like ER kinase

PDI Protein disulfide isomerase

ROS Reactive oxygene species

RIDD Regulated IRE1-dependent decay

SERCA Sarcoplasmic/endoplasmic $\mathrm{Ca}^{2+}$ ATPase

S1P Site-1 protease

S2P Site-2 protease

TPs Tocopherols 
TRAF2 Tumor necrosis factor receptor-associated factor 2

TTs Tocotrienols

UPR Unfolded protein response

XBP1 X-box binding protein 1

\section{References}

1. Porter, K.R.; Claude, A.; Fullam, E.F. A study of tissue culture cells by electron microscopy: Methods and preliminary observations. J. Exp. Med. 1945, 81, 233-246. [CrossRef] [PubMed]

2. Oakes, S.A.; Papa, F.R. The Role of Endoplasmic Reticulum Stress in Human Pathology. Annu. Rev. Pathol. Mech. Dis. 2015, 10, 173-194. [CrossRef] [PubMed]

3. Almanza, A.; Carlesso, A.; Chintha, C.; Creedican, S.; Doultsinos, D.; Leuzzi, B.; Luís, A.; McCarthy, N.; Montibeller, L.; More, S.; et al. Endoplasmic reticulum stress signalling - from basic mechanisms to clinical applications. FEBS J. 2018. [CrossRef]

4. Kim, I.; Xu, W.; Reed, J.C. Cell death and endoplasmic reticulum stress: Disease relevance and therapeutic opportunities. Nat. Rev. Drug Discov. 2008, 7, 1013-1030. [CrossRef] [PubMed]

5. Csala, M.; Kereszturi, É.; Mandl, J.; Bánhegyi, G. The Endoplasmic Reticulum As the Extracellular Space Inside the Cell: Role in Protein Folding and Glycosylation. Antioxid. Redox Signal. 2012, 16, 1100-1108. [CrossRef] [PubMed]

6. Maurel, M.; McGrath, E.P.; Mnich, K.; Healy, S.; Chevet, E.; Samali, A. Controlling the unfolded protein response-mediated life and death decisions in cancer. Semin. Cancer Biol. 2015, 33, 57-66. [CrossRef] [PubMed]

7. Mori, K. The unfolded protein response: The dawn of a new field. Proc. Jpn. Acad. Ser. B Phys. Biol. Sci. 2015, 91, 469-480. [CrossRef]

8. Wang, M.; Law, M.E.; Castellano, R.K.; Law, B.K. The unfolded protein response as a target for anticancer therapeutics. Crit. Rev. Oncol. Hematol. 2018, 127, 66-79. [CrossRef]

9. Martinon, F.; Chen, X.; Lee, A.-H.; Glimcher, L.H. TLR activation of the transcription factor XBP1 regulates innate immune responses in macrophages. Nat. Immunol. 2010, 11, 411-418. [CrossRef]

10. Hu, C.-C.A.; Dougan, S.K.; McGehee, A.M.; Love, J.C.; Ploegh, H.L. XBP-1 regulates signal transduction, transcription factors and bone marrow colonization in B cells. EMBO J. 2009, 28, 1624-1636. [CrossRef]

11. Bray, F.; Ferlay, J.; Soerjomataram, I.; Siegel, R.L.; Torre, L.A.; Jemal, A. Global cancer statistics 2018: GLOBOCAN estimates of incidence and mortality worldwide for 36 cancers in 185 countries. CA. Cancer J. Clin. 2018, 68, 394-424. [CrossRef] [PubMed]

12. Kingston, D.G.; Newman, D.J. Natural products as drug leads: An old process or the new hope for drug discovery? J. Med. Chem. 2008, 51, 2589-2599.

13. Menezes, J.C.J.M.D.S.; Orlikova, B.; Morceau, F.; Diederich, M. Natural and Synthetic Flavonoids: Structure-Activity Relationship and Chemotherapeutic Potential for the Treatment of Leukemia. Crit. Rev. Food Sci. Nutr. 2016, 56 (Suppl. 1), S4-S28. [CrossRef]

14. Kotecha, R.; Takami, A.; Espinoza, J.L. Dietary phytochemicals and cancer chemoprevention: A review of the clinical evidence. Oncotarget 2016, 7, 52517-52529. [CrossRef] [PubMed]

15. Singh, S.; Sharma, B.; Kanwar, S.S.; Kumar, A. Lead Phytochemicals for Anticancer Drug Development. Front. Plant Sci. 2016, 7, 1-13. [CrossRef] [PubMed]

16. de Oliveira Júnior, R.G.; Christiane Adrielly, A.F.; da Silva Almeida, J.R.G.; Grougnet, R.; Thiéry, V.; Picot, L. Sensitization of tumor cells to chemotherapy by natural products: A systematic review of preclinical data and molecular mechanisms. Fitoterapia 2018, 129, 383-400. [CrossRef] [PubMed]

17. Gardner, B.M.; Pincus, D.; Gotthardt, K.; Gallagher, C.M.; Walter, P. Endoplasmic Reticulum Stress Sensing in the Unfolded Protein Response. Cold Spring Harb. Perspect. Biol. 2013, 5, a013169. [CrossRef]

18. Sun, H.; Lin, D.-C.; Guo, X.; Kharabi Masouleh, B.; Gery, S.; Cao, Q.; Alkan, S.; Ikezoe, T.; Akiba, C.; Paquette, R.; et al. Inhibition of IRE1 $\alpha$-driven pro-survival pathways is a promising therapeutic application in acute myeloid leukemia. Oncotarget 2016, 7, 18736-18749. [CrossRef]

19. Lee, A.-H.; Glimcher, L.H. Intersection of the unfolded protein response and hepatic lipid metabolism. Cell. Mol. Life Sci. 2009, 66, 2835-2850. [CrossRef] 
20. Chen, Y.; Brandizzi, F. IRE1: ER stress sensor and cell fate executor. Trends Cell Biol. 2013, 23, 547-555. [CrossRef]

21. Clarke, H.J.; Chambers, J.E.; Liniker, E.; Marciniak, S.J. Endoplasmic Reticulum Stress in Malignancy. Cancer Cell 2014, 25, 563-573. [CrossRef] [PubMed]

22. Nishitoh, H.; Matsuzawa, A.; Tobiume, K.; Saegusa, K.; Takeda, K.; Inoue, K.; Hori, S.; Kakizuka, A.; Ichijo, H. ASK1 is essential for endoplasmic reticulum stress-induced neuronal cell death triggered by expanded polyglutamine repeats. Genes Dev. 2002, 16, 1345-1355. [CrossRef] [PubMed]

23. DuRose, J.B.; Scheuner, D.; Kaufman, R.J.; Rothblum, L.I.; Niwa, M. Phosphorylation of Eukaryotic Translation Initiation Factor 2 Coordinates rRNA Transcription and Translation Inhibition during Endoplasmic Reticulum Stress. Mol. Cell. Biol. 2009, 29, 4295-4307. [CrossRef] [PubMed]

24. Rozpedek, W.; Pytel, D.; Mucha, B.; Leszczynska, H.; Diehl, J.A.; Majsterek, I. The Role of the PERK/eIF2 $\alpha /$ ATF4/CHOP Signaling Pathway in Tumor Progression During Endoplasmic Reticulum Stress. Curr. Mol. Med. 2016, 16, 533-544. [CrossRef]

25. Zong, Z.-H.; Du, Z.-X.; Li, N.; Li, C.; Zhang, Q.; Liu, B.-Q.; Guan, Y.; Wang, H.-Q. Implication of Nrf2 and ATF4 in differential induction of CHOP by proteasome inhibition in thyroid cancer cells. Biochim. Biophys. Acta 2012, 1823, 1395-1404. [CrossRef] [PubMed]

26. Cabrera, E.; Hernández-Pérez, S.; Koundrioukoff, S.; Debatisse, M.; Kim, D.; Smolka, M.B.; Freire, R.; Gillespie, D.A. PERK inhibits DNA replication during the Unfolded Protein Response via Claspin and Chk1. Oncogene 2017, 36, 678-686. [CrossRef] [PubMed]

27. Hillary, R.F.; FitzGerald, U. A lifetime of stress: ATF6 in development and homeostasis. J. Biomed. Sci. 2018, 25, 48. [CrossRef]

28. Thuerauf, D.J.; Marcinko, M.; Belmont, P.J.; Glembotski, C.C. Effects of the Isoform-specific Characteristics of ATF6 $\alpha$ and ATF6 $\beta$ on Endoplasmic Reticulum Stress Response Gene Expression and Cell Viability. J. Biol. Chem. 2007, 282, 22865-22878. [CrossRef]

29. Hirsch, I.; Weiwad, M.; Prell, E.; Ferrari, D.M. ERp29 deficiency affects sensitivity to apoptosis via impairment of the ATF6-CHOP pathway of stress response. Apoptosis 2014, 19, 801-815. [CrossRef]

30. Kim, C.; Kim, B. Anti-Cancer Natural Products and Their Bioactive Compounds Inducing ER Stress-Mediated Apoptosis: A Review. Nutrients 2018, 10, 1021. [CrossRef]

31. Madden, E.; Logue, S.E.; Healy, S.J.; Manie, S.; Samali, A. The role of the unfolded protein response in cancer progression: From oncogenesis to chemoresistance. Biol. Cell 2019, 111, 1-17. [CrossRef] [PubMed]

32. Iurlaro, R.; Muñoz-Pinedo, C. Cell death induced by endoplasmic reticulum stress. FEBS J. 2016, 283, 2640-2652. [CrossRef]

33. Urano, F.; Bertolotti, A.; Ron, D. IRE1 and efferent signaling from the endoplasmic reticulum. J. Cell Sci. 2000, 113 Pt 21, 3697-3702.

34. Hetz, C.; Bernasconi, P.; Fisher, J.; Lee, A.H.; Bassik, M.C.; Antonsson, B.; Brandt, G.S.; Iwakoshi, N.N.; Schrinzel, A.; Glimcher, L.H.; et al. Proapoptotic BAX and BAK modulate the unfolded protein response by a direct interaction with IRE1 $\alpha$. Science 2006, 321, 572-576. [CrossRef]

35. Koong, A.C.; Chauhan, V.; Romero-Ramirez, L. Targeting XBP-1 as a novel anti-cancer strategy. Cancer Biol. Ther. 2006, 5, 756-759. [CrossRef] [PubMed]

36. Yang, Y.; Liu, L.; Naik, I.; Braunstein, Z.; Zhong, J.; Ren, B. Transcription Factor C/EBP Homologous Protein in Health and Diseases. Front. Immunol. 2017, 8, 1612. [CrossRef] [PubMed]

37. Oyadomari, S.; Mori, M. Roles of CHOP/GADD153 in endoplasmic reticulum stress. Cell Death Differ. 2004, 11,381-389. [CrossRef] [PubMed]

38. Ozcan, L.; Tabas, I. Pivotal role of calcium/calmodulin-dependent protein kinase II in ER stress-induced apoptosis. Cell Cycle 2010, 9, 223-224. [CrossRef]

39. Yamaguchi, H.; Wang, H.-G. CHOP Is Involved in Endoplasmic Reticulum Stress-induced Apoptosis by Enhancing DR5 Expression in Human Carcinoma Cells. J. Biol. Chem. 2004, 279, 45495-45502. [CrossRef]

40. Puthalakath, H.; O’Reilly, L.A.; Gunn, P.; Lee, L.; Kelly, P.N.; Huntington, N.D.; Hughes, P.D.; Michalak, E.M.; McKimm-Breschkin, J.; Motoyama, N.; et al. ER stress triggers apoptosis by activating BH3-only protein Bim. Cell 2007, 129, 1337-1349. [CrossRef]

41. Tan, B.; Jia, R.; Wang, G.; Yang, J. Astragaloside attenuates the progression of prostate cancer cells through endoplasmic reticulum stress pathways. Oncol. Lett. 2018, 16, 3901-3906. [CrossRef] [PubMed] 
42. Heath-Engel, H.M.; Wang, B.; Shore, G.C. Bcl2 at the endoplasmic reticulum protects against a Bax/Bak-independent paraptosis-like cell death pathway initiated via p20Bap31. Biochim. Biophys. Acta 2012, 1823, 335-347. [CrossRef] [PubMed]

43. Nieto-Miguel, T.; Fonteriz, R.I.; Vay, L.; Gajate, C.; López-Hernández, S.; Mollinedo, F. Endoplasmic reticulum stress in the proapoptotic action of edelfosine in solid tumor cells. Cancer Res. 2007, 67, 10368-10378. [CrossRef] [PubMed]

44. Logue, S.E.; McGrath, E.P.; Cleary, P.; Greene, S.; Mnich, K.; Almanza, A.; Chevet, E.; Dwyer, R.M.; Oommen, A.; Legembre, P.; et al. Inhibition of IRE1 RNase activity modulates the tumor cell secretome and enhances response to chemotherapy. Nat. Commun. 2018, 9, 3267. [CrossRef] [PubMed]

45. Chen, X.; Iliopoulos, D.; Zhang, Q.; Tang, Q.; Greenblatt, M.B.; Hatziapostolou, M.; Lim, E.; Tam, W.L.; Ni, M.; Chen, Y.; et al. XBP1 promotes triple-negative breast cancer by controlling the HIF1 $\alpha$ pathway. Nature 2014, 508, 103-107. [CrossRef] [PubMed]

46. Feng, Y.-x.; Sokol, E.S.; Del Vecchio, C.A.; Sanduja, S.; Claessen, J.H.L.; Proia, T.A.; Jin, D.X.; Reinhardt, F.; Ploegh, H.L.; Wang, Q.; et al. Epithelial-to-Mesenchymal Transition Activates PERK-eIF2 and Sensitizes Cells to Endoplasmic Reticulum Stress. Cancer Discov. 2014, 4, 702-715. [CrossRef]

47. Cuevas, E.P.; Eraso, P.; Mazón, M.J.; Santos, V.; Moreno-Bueno, G.; Cano, A.; Portillo, F. LOXL2 drives epithelial-mesenchymal transition via activation of IRE1-XBP1 signalling pathway. Sci. Rep. 2017, 7, 44988. [CrossRef]

48. Kim, J.K.; Kang, K.A.; Piao, M.J.; Ryu, Y.S.; Han, X.; Fernando, P.M.D.J.; Oh, M.C.; Park, J.E.; Shilnikova, K.; Boo, S.J.; et al. Endoplasmic reticulum stress induces 5-fluorouracil resistance in human colon cancer cells. Environ. Toxicol. Pharmacol. 2016, 44, 128-133. [CrossRef]

49. Chen, O.I.; Bobak, Y.P.; Stasyk, O.V.; Kunz-Schughart, L.A. A Complex Scenario and Underestimated Challenge: The Tumor Microenvironment, ER Stress, and Cancer Treatment. Curr. Med. Chem. 2018, 25, 2465-2502. [CrossRef]

50. Schüz, J.; Espina, C.; Villain, P.; Herrero, R.; Leon, M.E.; Minozzi, S.; Romieu, I.; Segnan, N.; Wardle, J.; Wiseman, M.; et al. European Code against Cancer 4th Edition: 12 ways to reduce your cancer risk. Cancer Epidemiol. 2015, 39, S1-S10. [CrossRef]

51. Singh, M.; Suman, S.; Shukla, Y. New enlightenment of skin cancer chemoprevention through phytochemicals: In vitro and in vivo studies and the underlying mechanisms. Biomed Res. Int. 2014, 2014, 243452. [CrossRef]

52. Mao, X.-Y.; Jin, M.-Z.; Chen, J.-F.; Zhou, H.-H.; Jin, W.-L. Live or let die: Neuroprotective and anti-cancer effects of nutraceutical antioxidants. Pharmacol. Ther. 2018, 183, 137-151. [CrossRef]

53. Leary, M.; Heerboth, S.; Lapinska, K.; Sarkar, S. Sensitization of drug resistant cancer cells: A matter of combination therapy. Cancers 2018, 10, 483. [CrossRef] [PubMed]

54. Catanzaro, E.; Greco, G.; Potenza, L.; Calcabrini, C.; Fimognari, C. Natural products to fight cancer: A focus on Juglans regia. Toxins 2018, 10, 469. [CrossRef] [PubMed]

55. Calcabrini, C.; Catanzaro, E.; Bishayee, A.; Turrini, E.; Fimognari, C. Marine Sponge Natural Products with Anticancer Potential: An Updated Review. Mar. Drugs 2017, 15, 310. [CrossRef]

56. Cha, J.; Song, H.-S.; Kang, B.; Park, M.; Park, K.; Kim, S.-H.; Shim, B.-S.; Kim, B. miR-211 Plays a Critical Role in Cnidium officinale Makino Extract-Induced, ROS/ER Stress-Mediated Apoptosis in U937 and U266 Cells. Int. J. Mol. Sci. 2018, 19, 865. [CrossRef]

57. Shehzad, A.; Wahid, F.; Lee, Y.S. Curcumin in cancer chemoprevention: Molecular targets, pharmacokinetics, bioavailability, and clinical trials. Arch. Pharm. 2010, 343, 489-499. [CrossRef]

58. Garrido-Armas, M.; Corona, J.C.; Escobar, M.L.; Torres, L.; Ordóñez-Romero, F.; Hernández-Hernández, A.; Arenas-Huertero, F. Paraptosis in human glioblastoma cell line induced by curcumin. Toxicol. Vitr. 2018, 51, 63-73. [CrossRef]

59. Rivera, M.; Ramos, Y.; Rodríguez-Valentín, M.; López-Acevedo, S.; Cubano, L.A.; Zou, J.; Zhang, Q.; Wang, G.; Boukli, N.M. Targeting multiple pro-apoptotic signaling pathways with curcumin in prostate cancer cells. PLoS One 2017, 12, e0179587. [CrossRef]

60. Huang, A.-C.; Chang, C.-L.; Yu, C.-S.; Chen, P.-Y.; Yang, J.-S.; Ji, B.-C.; Lin, T.-P.; Chiu, C.-F.; Yeh, S.-P.; Huang, Y.-P.; et al. Induction of apoptosis by curcumin in murine myelomonocytic leukemia WEHI-3 cells is mediated via endoplasmic reticulum stress and mitochondria-dependent pathways. Environ. Toxicol. 2013, 28, 255-266. [CrossRef] 
61. Roberts, J.L.; Poklepovic, A.; Booth, L. Curcumin interacts with sildenafil to kill GI tumor cells via endoplasmic reticulum stress and reactive oxygen/ nitrogen species. Oncotarget 2017, 8, 99451-99469. [CrossRef] [PubMed]

62. Huang, Y.-F.; Zhu, D.-J.; Chen, X.-W.; Chen, Q.-K.; Luo, Z.-T.; Liu, C.-C.; Wang, G.-X.; Zhang, W.-J.; Liao, N.-Z. Curcumin enhances the effects of irinotecan on colorectal cancer cells through the generation of reactive oxygen species and activation of the endoplasmic reticulum stress pathway. Oncotarget 2017, 8, 40264. [CrossRef] [PubMed]

63. Yang, S.-T.; Huang, A.-C.; Tang, N.-Y.; Liu, H.-C.; Liao, C.-L.; Ji, B.-C.; Chou, Y.-C.; Yang, M.-D.; Lu, H.-F.; Chung, J.-G. Bisdemethoxycurcumin-induced S phase arrest through the inhibition of cyclin A and $\mathrm{E}$ and induction of apoptosis via endoplasmic reticulum stress and mitochondria-dependent pathways in human lung cancer NCI H460 cells. Environ. Toxicol. 2016, 31, 1899-1908. [CrossRef] [PubMed]

64. Ko, Y.-C.; Lien, J.-C.; Liu, H.-C.; Hsu, S.-C.; Ji, B.-C.; Yang, M.-D.; Hsu, W.-H.; Chung, J.-G. Demethoxycurcumin induces the apoptosis of human lung cancer NCI-H460 cells through the mitochondrial-dependent pathway. Oncol. Rep. 2015, 33, 2429-2437. [CrossRef] [PubMed]

65. Zheng, A.; Li, H.; Wang, X.; Feng, Z.; Xu, J.; Cao, K.; Zhou, B.; Wu, J.; Liu, J. Anticancer Effect of a Curcumin Derivative B63: ROS Production and Mitochondrial Dysfunction. Curr. Cancer Drug Targets 2014, 14, 156-166. [CrossRef] [PubMed]

66. Zhang, X.; Zhang, H.Q.; Zhu, G.H.; Wang, Y.H.; Yu, X.C.; Zhu, X.B.; Liang, G.; Xiao, J.; Li, X.K. A novel mono-carbonyl analogue of curcumin induces apoptosis in ovarian oxygen species production. Mol Med Rep. 2012, 5, 739-744. [PubMed]

67. Dai, X.; Zhang, J.; Guo, G.; Cai, Y.; Cui, R.; Yin, C.; Liu, W.; Vinothkumar, R.; Zhang, T.; Liang, G.; et al. A mono-carbonyl analog of curcumin induces apoptosis in drug-resistant EGFR-mutant lung cancer through the generation of oxidative stress and mitochondrial dysfunction. Cancer Manag. Res. 2018, 10, 3069-3082. [CrossRef]

68. Chang, L.-C.; Hsieh, M.-T.; Yang, J.-S.; Lu, C.-C.; Tsai, F.-J.; Tsao, J.-W.; Chiu, Y.-J.; Kuo, S.-C.; Lee, K.-H. Effect of bis(hydroxymethyl) alkanoate curcuminoid derivative MTH-3 on cell cycle arrest, apoptotic and autophagic pathway in triple-negative breast adenocarcinoma MDA-MB-231 cells: An in vitro study. Int. J. Oncol. 2017, 52, 67-76. [CrossRef]

69. Biagi, M.; Bertelli, A.A.E. Wine, alcohol and pills: What future for the French paradox? Life Sci. 2015, 131, 19-22. [CrossRef]

70. Elshaer, M.; Chen, Y.; Wang, X.J.; Tang, X. Resveratrol: An overview of its anti-cancer mechanisms. Life Sci. 2018, 207, 340-349. [CrossRef]

71. Wang, F.-M.; Galson, D.L.; Roodman, G.D.; Ouyang, H. Resveratrol triggers the pro-apoptotic endoplasmic reticulum stress response and represses pro-survival XBP1 signaling in human multiple myeloma cells. Exp. Hematol. 2011, 39, 999-1006. [CrossRef]

72. Heo, J.; Kim, S.; Hwang, K.; Kang, J.; Choi, K. Resveratrol induced reactive oxygen species and endoplasmic reticulum stress-mediated apoptosis, and cell cycle arrest in the A375SM malignant melanoma cell line. Int. J. Mol. Med. 2018, 42, 1427-1435. [CrossRef] [PubMed]

73. Rojas, C.; Pan-Castillo, B.; Valls, C.; Pujadas, G.; Garcia-Vallve, S.; Arola, L.; Mulero, M. Resveratrol enhances palmitate-induced ER stress and apoptosis in cancer cells. PLoS One 2014, 9, e113929. [CrossRef] [PubMed]

74. Bai, T.; Dong, D.-S.; Pei, L. Synergistic antitumor activity of resveratrol and miR-200c in human lung cancer. Oncol. Rep. 2014, 31, 2293-2297. [CrossRef] [PubMed]

75. Chow, S.-E.; Kao, C.-H.; Liu, Y.-T.A.; Cheng, M.-L.; Yang, Y.-W.; Huang, Y.-K.; Hsu, C.-C.; Wang, J.-S. Resveratrol induced ER expansion and ER caspase-mediated apoptosis in human nasopharyngeal carcinoma cells. Apoptosis 2014, 19, 527-541. [CrossRef] [PubMed]

76. Gu, S.; Chen, C.; Jiang, X.; Zhang, Z. ROS-mediated endoplasmic reticulum stress and mitochondrial dysfunction underlie apoptosis induced by resveratrol and arsenic trioxide in A549 cells. Chem. Biol. Interact. 2016, 245, 100-109. [CrossRef]

77. Gwak, H.; Kim, S.; Dhanasekaran, D.N.; Song, Y.S. Resveratrol triggers ER stress-mediated apoptosis by disrupting N -linked glycosylation of proteins in ovarian cancer cells. Cancer Lett. 2016, 371, 347-353. [CrossRef] [PubMed]

78. Wang, P.; Sang, S. Metabolism and pharmacokinetics of resveratrol and pterostilbene. Biofactors 2018, 44, 16-25. [CrossRef] 
79. Fan, X.-X.; Yao, X.-J.; Xu, S.W.; Wong, V.K.-W.; He, J.-X.; Ding, J.; Xue, W.-W.; Mujtaba, T.; Michelangeli, F.; Huang, M.; et al. (Z)3,4,5,4'-trans-tetramethoxystilbene, a new analogue of resveratrol, inhibits gefitinb-resistant non-small cell lung cancer via selectively elevating intracellular calcium level. Sci. Rep. 2015, 5, 16348. [CrossRef]

80. Feng, Y.; Yang, Y.; Fan, C.; Di, S.; Hu, W.; Jiang, S.; Li, T.; Ma, Z.; Chao, D.; Feng, X.; et al. Pterostilbene Inhibits the Growth of Human Esophageal Cancer Cells by Regulating Endoplasmic Reticulum Stress. Cell. Physiol. Biochem. 2016, 38, 1226-1244. [CrossRef]

81. Park, J.; Choi, W.; Lee, P.; Chung, S.; Kim, B.; Chung, H.; Cho, S.; Kim, J.; Kang, B.; Kim, H.; et al. The novel resveratrol derivative 3,5-diethoxy-3', $4^{\prime}$-dihydroxy-trans-stilbene induces mitochondrial ROS-mediated ER stress and cell death in human hepatoma cells in vitro. Acta Pharmacol. Sin. 2017, 38, 1486-1500. [CrossRef] [PubMed]

82. Révész, K.; Tütto, A.; Szelényi, P.; Konta, L. Tea flavan-3-ols as modulating factors in endoplasmic reticulum function. Nutr. Res. 2011, 31, 731-740. [CrossRef] [PubMed]

83. Davalli, P.; Rizzi, F.; Caldara, G.F.; Davoli, S.; Corti, A.; Silva, A.; Astancolle, S.; Vitale, M.; Bettuzzi, S.; Arcari, M.; et al. Chronic administration of green tea extract to TRAMP mice induces the collapse of Golgi apparatus in prostate secretory cells and results in alterations of protein post-translational processing. Int. J. Oncol. 2011, 39, 1521-1527. [PubMed]

84. Rizzi, F.; Naponelli, V.; Silva, A.; Modernelli, A.; Ramazzina, I.; Bonacini, M.; Tardito, S.; Gatti, R.; Uggeri, J.; Bettuzzi, S. Polyphenon $\mathrm{E}^{\circledR}$, a standardized green tea extract, induces endoplasmic reticulum stress, leading to death of immortalized PNT1a cells by anoikis and tumorigenic PC3 by necroptosis. Carcinogenesis 2014, 35, 828-839. [CrossRef] [PubMed]

85. Modernelli, A.; Naponelli, V.; Giovanna Troglio, M.; Bonacini, M.; Ramazzina, I.; Bettuzzi, S.; Rizzi, F. EGCG antagonizes Bortezomib cytotoxicity in prostate cancer cells by an autophagic mechanism. Sci. Rep. 2015, 5, 15270. [CrossRef] [PubMed]

86. Martinotti, S.; Ranzato, E.; Burlando, B. (-)- Epigallocatechin-3-gallate induces GRP78 accumulation in the ER and shifts mesothelioma constitutive UPR into proapoptotic ER stress. J. Cell. Physiol. 2018. [CrossRef]

87. Xie, J.; Yun, J.; Yang, Y.; Hua, F.; Zhang, X.; Lin, H.; Lv, X.; Li, K.; Zhang, P.; Hu, Z. A novel ECG analog 4-(S)-(2,4,6-trimethylthiobenzyl)-epigallocatechin gallate selectively induces apoptosis of B16-F10 melanoma via activation of autophagy and ROS. Sci. Rep. 2017, 7, 42194. [CrossRef]

88. Huang, K.-H.; Kuo, K.-L.; Chen, S.-C.; Weng, T.-I.; Chuang, Y.-T.; Tsai, Y.-C.; Pu, Y.-S.; Chiang, C.-K.; Liu, S.-H. Down-regulation of glucose-regulated protein (GRP) 78 potentiates cytotoxic effect of celecoxib in human urothelial carcinoma cells. PLoS One 2012, 7, e33615. [CrossRef]

89. Huang, X.; Li, L.; Zhang, L.; Zhang, Z.; Wang, X.; Zhang, X.; Hou, L.; Wu, K. Crosstalk between endoplasmic reticulum stress and oxidative stress in apoptosis induced by $\alpha$-tocopheryl succinate in human gastric carcinoma cells. Br. J. Nutr. 2013, 109, 727-735. [CrossRef]

90. Marzagalli, M.; Moretti, R.M.; Messi, E.; Marelli, M.M.; Fontana, F.; Anastasia, A.; Bani, M.R.; Beretta, G.; Limonta, P. Targeting melanoma stem cells with the Vitamin E derivative $\delta$-tocotrienol. Sci. Rep. 2018, 8, 587. [CrossRef]

91. Montagnani Marelli, M.; Marzagalli, M.; Fontana, F.; Raimondi, M.; Moretti, R.M.; Limonta, P. Anticancer properties of tocotrienols: A review of cellular mechanisms and molecular targets. J. Cell. Physiol. 2019, 234, 1147-1164. [CrossRef]

92. Wali, V.B.; Bachawal, S.V.; Sylvester, P.W. Endoplasmic reticulum stress mediates gamma-tocotrienol-induced apoptosis in mammary tumor cells. Apoptosis 2009, 14, 1366-1377. [CrossRef] [PubMed]

93. Park, S.K.; Sanders, B.G.; Kline, K. Tocotrienols induce apoptosis in breast cancer cell lines via an endoplasmic reticulum stress-dependent increase in extrinsic death receptor signaling. Breast Cancer Res. Treat. 2010, 124, 361-375. [CrossRef] [PubMed]

94. Patacsil, D.; Tran, A.T.; Cho, Y.S.; Suy, S.; Saenz, F.; Malyukova, I.; Ressom, H.; Collins, S.P.; Clarke, R.; Kumar, D. Gamma-tocotrienol induced apoptosis is associated with unfolded protein response in human breast cancer cells. J. Nutr. Biochem. 2012, 23, 93-100. [CrossRef] [PubMed]

95. Tiwari, R.V.; Parajuli, P.; Sylvester, P.W. $\gamma$-Tocotrienol-induced endoplasmic reticulum stress and autophagy act concurrently to promote breast cancer cell death. Biochem. Cell Biol. 2015, 93, 306-320. [CrossRef] [PubMed] 
96. Comitato, R.; Guantario, B.; Leoni, G.; Nesaretnam, K.; Ronci, M.B.; Canali, R.; Virgili, F. Tocotrienols induce endoplasmic reticulum stress and apoptosis in cervical cancer cells. Genes Nutr. 2016, 11, 32. [CrossRef]

97. Montagnani Marelli, M.; Marzagalli, M.; Moretti, R.M.; Beretta, G.; Casati, L.; Comitato, R.; Gravina, G.L.; Festuccia, C.; Limonta, P. Vitamin E $\delta$-tocotrienol triggers endoplasmic reticulum stress-mediated apoptosis in human melanoma cells. Sci. Rep. 2016, 6, 30502. [CrossRef] [PubMed]

98. Xie, Z.; Sintara, M.; Chang, T.; Ou, B. Daily consumption of a mangosteen-based drink improves in vivo antioxidant and anti-inflammatory biomarkers in healthy adults: A randomized, double-blind, placebo-controlled clinical trial. Food Sci. Nutr. 2015, 3, 342-348. [CrossRef]

99. Kritsanawong, S.; Innajak, S.; Imoto, M.; Watanapokasin, R. Antiproliferative and apoptosis induction of $\alpha$-mangostin in T47D breast cancer cells. Int. J. Oncol. 2016, 48, 2155-2165. [CrossRef]

100. Sato, A.; Fujiwara, H.; Oku, H.; Ishiguro, K.; Ohizumi, Y. Alpha-mangostin induces Ca2+-ATPase-dependent apoptosis via mitochondrial pathway in PC12 cells. J. Pharmacol. Sci. 2004, 95, 33-40. [CrossRef]

101. Li, G.; Petiwala, S.M.; Pierce, D.R.; Nonn, L.; Johnson, J.J. Selective modulation of endoplasmic reticulum stress markers in prostate cancer cells by a standardized mangosteen fruit extract. PLoS One 2013, 8. [CrossRef] [PubMed]

102. Li, G.; Petiwala, S.M.; Nonn, L.; Johnson, J.J. Inhibition of CHOP accentuates the apoptotic effect of $\alpha$-mangostin from the mangosteen fruit (Garcinia mangostana) in 22Rv1 prostate cancer cells. Biochem. Biophys. Res. Commun. 2014, 453, 75-80. [CrossRef] [PubMed]

103. Xu, X.-H.; Liu, Q.-Y.; Li, T.; Liu, J.-L.; Chen, X.; Huang, L.; Qiang, W.-A.; Chen, X.; Wang, Y.; Lin, L.-G.; et al. Garcinone E induces apoptosis and inhibits migration and invasion in ovarian cancer cells. Sci. Rep. 2017, 7, 10718. [CrossRef] [PubMed]

104. Liu, Z.; Antalek, M.; Nguyen, L.; Li, X.; Tian, X.; Le, A.; Zi, X. The Effect of Gartanin, a Naturally Occurring Xanthone in Mangosteen Juice, on the mTOR Pathway, Autophagy, Apoptosis, and the Growth of Human Urinary Bladder Cancer Cell Lines. Nutr. Cancer 2013, 65, 68-77. [CrossRef] [PubMed]

105. Li, G.; Petiwala, S.M.; Yan, M.; Won, J.H.; Petukhov, P.A.; Johnson, J.J. Gartanin, an isoprenylated xanthone from the mangosteen fruit (Garcinia mangostana), is an androgen receptor degradation enhancer. Mol. Nutr. Food Res. 2016, 60, 1458-1469. [CrossRef] [PubMed]

106. Cheng, A.-C.; Tsai, M.-L.; Liu, C.-M.; Lee, M.-F.; Nagabhushanam, K.; Ho, C.-T.; Pan, M.-H. Garcinol inhibits cell growth in hepatocellular carcinoma Hep3B cells through induction of ROS-dependent apoptosis. Food Funct. 2010, 1, 301. [CrossRef] [PubMed]

107. Nie, F.; Zhang, X.; Qi, Q.; Yang, L.; Yang, Y.; Liu, W.; Lu, N.; Wu, Z.; You, Q.; Guo, Q. Reactive oxygen species accumulation contributes to gambogic acid-induced apoptosis in human hepatoma SMMC-7721 cells. Toxicology 2009, 260, 60-67. [CrossRef] [PubMed]

108. Li, R.; Chen, Y.; Zeng, L.; Shu, W.; Zhao, F.; Wen, L.; Liu, Y. Gambogic acid induces G0/G1 arrest and apoptosis involving inhibition of SRC-3 and inactivation of Akt pathway in K562 leukemia cells. Toxicology 2009, 262, 98-105. [CrossRef] [PubMed]

109. Krajarng, A.; Imoto, M.; Tashiro, E.; Fujimaki, T.; Shinjo, S.; Watanapokasin, R. Apoptosis induction associated with the ER stress response through up-regulation of JNK in HeLa cells by gambogic acid. BMC Complement. Altern. Med. 2015, 15, 26. [CrossRef] [PubMed]

110. Aghaei, M.; Ghanadian, M.; Sajjadi, S.E.; Saghafian, R.; Keyvanloo shahrestanaki, M. Pimpinelol, a novel atypical Sesquiterpene lactone from Pimpinella haussknechtii fruits with evaluation of endoplasmic reticulum stress in breast cancer cells. Fitoterapia 2018, 129, 198-202. [CrossRef]

111. Cevatemre, B.; Erkısa, M.; Aztopal, N.; Karakas, D.; Alper, P.; Tsimplouli, C.; Sereti, E.; Dimas, K.; Armutak, E.I.I.; Gurevin, E.G.; et al. A promising natural product, pristimerin, results in cytotoxicity against breast cancer stem cells in vitro and xenografts in vivo through apoptosis and an incomplete autopaghy in breast cancer. Pharmacol. Res. 2018, 129, 500-514. [CrossRef] [PubMed]

112. Kim, C.; Song, H.-S.; Park, H.; Kim, B. Activation of ER Stress-Dependent miR-216b Has a Critical Role in Salviamiltiorrhiza Ethanol-Extract-Induced Apoptosis in U266 and U937 Cells. Int. J. Mol. Sci. 2018, 19, 1240. [CrossRef] [PubMed]

113. Hu, K.; Yao, X. Methyl protogracillin (NSC-698792): The spectrum of cytotoxicity against 60 human cancer cell lines in the National Cancer Institute's anticancer drug screen panel. Anticancer. Drugs 2001, 12, 541-547. [CrossRef] [PubMed] 
114. Lin, C.-L.; Lee, C.-H.; Chen, C.-M.; Cheng, C.-W.; Chen, P.-N.; Ying, T.-H.; Hsieh, Y.-H. Protodioscin Induces Apoptosis Through ROS-Mediated Endoplasmic Reticulum Stress via the JNK/p38 Activation Pathways in Human Cervical Cancer Cells. Cell. Physiol. Biochem. 2018, 46, 322-334. [CrossRef] [PubMed]

115. Liu, Y.-H.; Weng, Y.-P.; Tsai, H.-Y.; Chen, C.-J.; Lee, D.-Y.; Hsieh, C.-L.; Wu, Y.-C.; Lin, J.-Y. Aqueous extracts of Paeonia suffruticosa modulates mitochondrial proteostasis by reactive oxygen species-induced endoplasmic reticulum stress in pancreatic cancer cells. Phytomedicine 2018, 46, 184-192. [CrossRef]

116. Lu, M.-C.; Li, T.-Y.; Hsieh, Y.-C.; Hsieh, P.-C.; Chu, Y.-L. Chemical evaluation and cytotoxic mechanism investigation of Clinacanthus nutans extract in lymphoma SUP-T1 cells. Environ. Toxicol. 2018, 33, 1229-1236. [CrossRef]

117. Chen, K.; Wang, C.-Q.; Fan, Y.-Q.; Xie, Y.-S.; Yin, Z.-F.; Xu, Z.-J.; Zhang, H.-L.; Cao, J.-T.; Wang, Y. Application of chrysophanol in zebrafish to reduce dietary introduced lipid and its possible mechanism. Int. J. Clin. Exp. Med. 2015, 8, 10558-10567.

118. Park, S.; Lim, W.; Song, G. Chrysophanol selectively represses breast cancer cell growth by inducing reactive oxygen species production and endoplasmic reticulum stress via AKT and mitogen-activated protein kinase signal pathways. Toxicol. Appl. Pharmacol. 2018, 360, 201-211. [CrossRef]

119. Kaschula, C.H.; Hunter, R.; Cotton, J.; Tuveri, R.; Ngarande, E.; Dzobo, K.; Schäfer, G.; Siyo, V.; Lang, D.; Kusza, D.A.; et al. The garlic compound ajoene targets protein folding in the endoplasmic reticulum of cancer cells. Mol. Carcinog. 2016, 55, 1213-1228. [CrossRef]

120. Siyo, V.; Schäfer, G.; Hunter, R.; Grafov, A.; Grafova, I.; Nieger, M.; Katz, A.A.; Parker, M.I.; Kaschula, C.H. The Cytotoxicity of the Ajoene Analogue BisPMB in WHCO1 Oesophageal Cancer Cells Is Mediated by CHOP/GADD153. Molecules 2017, 22, 892. [CrossRef]

121. Petrovic, V.; Nepal, A.; Olaisen, C.; Bachke, S.; Hira, J.; Søgaard, C.; Røst, L.; Misund, K.; Andreassen, T.; Melø, T.; et al. Anti-Cancer Potential of Homemade Fresh Garlic Extract Is Related to Increased Endoplasmic Reticulum Stress. Nutrients 2018, 10, 450. [CrossRef] [PubMed]

122. Tsai, T.-C.; Lai, K.-H.; Su, J.-H.; Wu, Y.-J.; Sheu, J.-H. 7-Acetylsinumaximol B Induces Apoptosis and Autophagy in Human Gastric Carcinoma Cells through Mitochondria Dysfunction and Activation of the PERK/eIF2 $\alpha$ /ATF4/CHOP Signaling Pathway. Mar. Drugs 2018, 16, 104. [CrossRef] [PubMed]

123. Alves-Fernandes, D.K.; Oliveira, É.A.; Faião-Flores, F.; Alicea-Rebecca, G.; Weeraratna, A.T.; Smalley, K.S.M.; de Moraes Barros, S.B.; Maria-Engler, S.S. ER stress promotes antitumor effects in BRAFi/MEKi resistant human melanoma induced by natural compound 4-nerolidylcathecol (4-NC). Pharmacol. Res. 2018, 141, 63-72. [CrossRef] [PubMed]

124. Tan, G.-X.; Wang, X.-N.; Tang, Y.-Y.; Cen, W.-J.; Li, Z.-H.; Wang, G.-C.; Jiang, J.-W.; Wang, X.-C. PP-22 promotes autophagy and apoptosis in the nasopharyngeal carcinoma cell line CNE-2 by inducing endoplasmic reticulum stress, downregulating STAT3 signaling, and modulating the MAPK pathway. J. Cell. Physiol. 2019, 234, 2618-2630. [CrossRef] [PubMed]

125. Gu, H.; Huang, T.; Shen, Y.; Liu, Y.; Zhou, F.; Jin, Y.; Sattar, H.; Wei, Y. Reactive Oxygen Species-Mediated Tumor Microenvironment Transformation: The Mechanism of Radioresistant Gastric Cancer. Oxid. Med. Cell. Longev. 2018, 2018, 5801209. [CrossRef] [PubMed]

126. Nunes, T.; Hamdan, D.; Leboeuf, C.; El Bouchtaoui, M.; Gapihan, G.; Nguyen, T.T.; Meles, S.; Angeli, E.; Ratajczak, P.; Lu, H.; et al. Targeting Cancer Stem Cells to Overcome Chemoresistance. Int. J. Mol. Sci. 2018, 19, 4036. [CrossRef] [PubMed]

127. Prieto-Vila, M.; Takahashi, R.; Usuba, W.; Kohama, I.; Ochiya, T. Drug Resistance Driven by Cancer Stem Cells and Their Niche. Int. J. Mol. Sci. 2017, 18, 2574. [CrossRef]

128. Tang, L.; Wei, F.; Wu, Y.; He, Y.; Shi, L.; Xiong, F.; Gong, Z.; Guo, C.; Li, X.; Deng, H.; et al. Role of metabolism in cancer cell radioresistance and radiosensitization methods. J. Exp. Clin. Cancer Res. 2018, 37, 87. [CrossRef]

129. Kesharwani, S.S.; Kaur, S.; Tummala, H.; Sangamwar, A.T. Multifunctional approaches utilizing polymeric micelles to circumvent multidrug resistant tumors. Colloids Surf. B. Biointerfaces 2019, 173, 581-590. [CrossRef]

130. Belli, C.; Trapani, D.; Viale, G.; D’Amico, P.; Duso, B.A.; Della Vigna, P.; Orsi, F.; Curigliano, G. Targeting the microenvironment in solid tumors. Cancer Treat. Rev. 2018, 65, 22-32. [CrossRef]

131. Chou, C.-K.; Liu, W.; Hong, Y.-J.; Dahms, H.-U.; Chiu, C.-H.; Chang, W.-T.; Chien, C.-M.; Yen, C.-H.; Cheng, Y.-B.; Chiu, C.-C. Ethyl acetate extract of Scindapsus cf. hederaceus exerts the inhibitory bioactivity on human non-small cell lung cancer cells through modulating ER stress. Int. J. Mol. Sci. 2018, 19, 1832. [CrossRef] 
132. Martin, S.; Lamb, H.K.; Brady, C.; Lefkove, B.; Bonner, M.Y.; Thompson, P.; Lovat, P.E.; Arbiser, J.L.; Hawkins, A.R.; Redfern, C.P.F. Inducing apoptosis of cancer cells using small-molecule plant compounds that bind to GRP78. Br. J. Cancer 2013, 109, 433-443. [CrossRef] [PubMed]

133. Virrey, J.J.; Dong, D.; Stiles, C.; Patterson, J.B.; Pen, L.; Ni, M.; Schonthal, A.H.; Chen, T.C.; Hofman, F.M.; Lee, A.S. Stress Chaperone GRP78/BiP Confers Chemoresistance to Tumor-Associated Endothelial Cells. Mol. Cancer Res. 2008, 6, 1268-1275. [CrossRef] [PubMed]

134. Ermakova, S.P.; Kang, B.S.; Choi, B.Y.; Choi, H.S.; Schuster, T.F.; Ma, W.-Y.; Bode, A.M.; Dong, Z. (-)-Epigallocatechin gallate overcomes resistance to etoposide-induced cell death by targeting the molecular chaperone glucose-regulated protein 78. Cancer Res. 2006, 66, 9260-9269. [CrossRef] [PubMed]

135. Chen, W.; Li, P.; Liu, Y.; Yang, Y.; Ye, X.; Zhang, F.; Huang, H. Isoalantolactone induces apoptosis through ROS-mediated ER stress and inhibition of STAT3 in prostate cancer cells. J. Exp. Clin. Cancer Res. 2018, 37, 309. [CrossRef] [PubMed]

136. Cai, Y.; Zheng, Y.; Gu, J.; Wang, S.; Wang, N.; Yang, B.; Zhang, F.; Wang, D.; Fu, W.; Wang, Z. Betulinic acid chemosensitizes breast cancer by triggering ER stress-mediated apoptosis by directly targeting GRP78. Cell Death Dis. 2018, 9, 636. [CrossRef]

137. Zhang, Q.-Y.; Wang, F.-X.; Jia, K.-K.; Kong, L.-D. Natural Product Interventions for Chemotherapy and Radiotherapy-Induced Side Effects. Front Pharmacol. 2018, 9, 1253. [CrossRef]

138. Mazumder, A.; Cerella, C.; Diederich, M. Natural scaffolds in anticancer therapy and precision medicine. Biotechnol. Adv. 2018, 36, 1563-1585. [CrossRef] [PubMed]

139. Vengoji, R.; Macha, M.A.; Batra, S.K.; Shonka, N.A. Natural products: A hope for glioblastoma patients. Oncotarget 2018, 9, 22194-22219. [CrossRef]

140. Kumar, M.S.; Adki, K.M. Marine natural products for multi-targeted cancer treatment: A future insight. Biomed. Pharmacother. 2018, 105, 233-245. [CrossRef]

141. Rietjens, I.M.C.M.; Louisse, J.; Beekmann, K. The potential health effects of dietary phytoestrogens. Br. J. Pharmacol. 2017, 174, 1263-1280. [CrossRef] [PubMed]

142. Chikara, S.; Nagaprashantha, L.D.; Singhal, J.; Horne, D.; Awasthi, S.; Singhal, S.S. Oxidative stress and dietary phytochemicals: Role in cancer chemoprevention and treatment. Cancer Lett. 2018, 413, 122-134. [CrossRef] [PubMed]

(C) 2019 by the authors. Licensee MDPI, Basel, Switzerland. This article is an open access article distributed under the terms and conditions of the Creative Commons Attribution (CC BY) license (http://creativecommons.org/licenses/by/4.0/). 